\title{
四塩化炭素頻回吸入マウス肝におけるセロイド色素 並びに血鉄素ないしフェリチン生成の電顕的研究
}

\author{
関西医科大学第一病理学教室（指導 前田隆英教授）
}

大学院学生 立 岩 二 朗

\section{I. 粕 贯}

四塩化炭素（以下: $\mathrm{CCl}_{4}$ ) 投与マウス肝大喰細胞に 於けるセロイド色素の出現の記載は Edwards ら (1942) 10) の報告を嗃失とするが，続いて Lee45) は唯 1 回の $\mathrm{CCl}_{4}$ 投与によってる投与後10〜14日で肝 Kupffer 細胞 内にセロイド色素が出現することを報じた。

しかしながら以後 $\mathrm{CCl}_{4}$ 投与実験の報告は啎出してい るにも拘らずセロイド色素の超微形態を系統的に記載し ているすのはほとんど見当らず，ましてセロイド色素の 生成過程を血鉄素のそれと関連つけけ超微形態的に観察 した報告はみられない。

他方,へモグロビン，鉄含有削(例えば iron-dextran) 等の非経口投与動物や鉄過剩トウモロコシ食慨飼育動 物（ラット，イヌ）の䀒臓におけるフェリチンないし血 鉄素の生成過程を光顕的 17) 40) 並びに電顕的 54) 64) 80) に観察した報告はかなりの数に達する.一方, $\mathrm{CCl}_{4}$, エ チオニン, 過量のアルコール等の盰障害郩投与動物に鉄 唁投与を併用して鉄の強い沈着を生じさせた動物旰のフ ェリチンや血鉄素の沈着過程の電影像を追求した報告む 多いが，同時にせロイド色素の出現を記載した 業蹟は 一，二みられるに過ぎず，この種の報告の中で Golberg ら 18) 19) 注光顕的レベルではあるが，セロイド色素の生 成機転に対する鉄の関与を論じている．他方，前田49) はセロイド色素が同一大喰細胞内で血鉄素と共存する光 顕的所見がしばしは見出されることに注目し，セロイド 色素が血液ことに赤血球に由来が求め得られる場合があ ることを想定し，次いで大和86) はとの実験的裏付けを 行なっている.

そこで著者は $\mathrm{CCl}_{4}$ 障害マウス肝を電顕的に観察し， Kupffer 細胞内に於て erythrophagocytosis の所見や セロイド色素が phagolysosome 内で多量のフェリチン ないし血鉄素と共存する所見がしばしば見出される点に 着眼して，これら所見を示す肝を材料としてセロイド色 素並びにフェリチンないし血鉄素の生成過程をKupffer
細胞内で超微形態的に追求することを試みた. その結 果, 両色素がその生成過程に於て密接な関連性を有する ことを思わせる知見が得られたので，この点に就て考察 した.

\section{II . 実験材料ならびに実医方法}

\section{A）使用動物}

本実験使用した動物は，自家繁殖した JCL ${ }^{\circledR} \mathrm{ICR}$ 系 マウス (ふ28頭, 早13頭) で, オリェンタル䤉母の CMF と水道水を自由に与えて飼育した。実験開始時の体重は 雄マウス 26.0 41.0 g, 倠マウス $21.0 \sim 27.5 \mathrm{~g} て ゙$, 生 後50〜100日の健常成熟マウスを用いた。

B ) 実験材料

JCL®ICR マウスに CCl4 ガス吸入操作*)を週 3 回の 割合で繰り返し行い，作製した $\mathrm{CCl}_{4}$ 中毒マウス（第 1 表) を断頭・鴵血ののち迅速に肝䁍を摘出し，その一部 を実験材料とした。

\section{C) 钼察方法}

\section{【方法 I】電子顕微鏡による観察方法.}

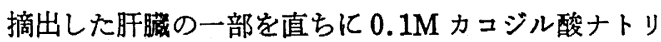
ウム緩衝夜で $\mathrm{pH} 7.4$ 亿調整した $2 \%$ \%ルタール・フルデ ヒド水溶液 [以下： $2 \%$ はルタール・フルデヒド固定液 (pH7.4)]に浸漬しながら細切, その細切小片を $4{ }^{\circ} \mathrm{C}$, $2 \%$ グルール・フルデヒド固定液（pH 7.4）で 2 時間 固定後, $4^{\circ} \mathrm{C}, 0.1 \mathrm{M}$ カコジル酸ナトリウム縓衝液 $(\mathrm{pH}$ 7.4）にて一晚洗熦した.つづて $0.1 \mathrm{M}$ 燐酸塩緩衝液で $\mathrm{pH} 7.4$ 亿調整した $4{ }^{\circ} \mathrm{C} ， 1 \%$ オスミウム酸水溶液で後固 定 (2 時間) した. その後, エタノール上昇系列で充分 脱水し, プロビレン・オキサイド漫漬後, Luft ${ }^{47)}$ の方 法飞従って Epon 812亿包埋. 超薄切片をガラスナイフ

*) $\mathrm{CCl}_{4}$ を浸み込ませたガーゼを底们敷きつめ $\mathrm{CCl}_{4}$ ガスを充満させだガラス性広口瓶にマウスを一頭ずつ 投入し，慎重な観察の下で致死寸前で広口瓶より取り 出す. 
第 1 表 実験マウス（四塩化炭索ガス吸入）

\begin{tabular}{|c|c|c|c|c|c|}
\hline 動 番 & 性 & 吸入回 数* & 放置期間 (週)** & 実験期間 (日)*** & 屠殺時体重 $(\mathrm{g})$ \\
\hline 1 & $\hat{\delta}$ & 1 & & 1 & 33.0 \\
\hline 2 & $\hat{\delta}$ & 1 & & 1 & 28.5 \\
\hline 3 & $\hat{\delta}$ & 1 & & 1 & 39.0 \\
\hline 4 & $\hat{\delta}$ & 1 & & 1 & 38.4 \\
\hline 5 & $\hat{o}$ & 2 & & 3 & 40.5 \\
\hline 6 & $\hat{\delta}$ & 2 & & 3 & 38.5 \\
\hline 7 & $\hat{\delta}$ & 3 & & 5 & 40.1 \\
\hline 8 & $\hat{\delta}$ & 5 & & 10 & 33.5 \\
\hline 9 & 우 & 5 & & 10 & 27.8 \\
\hline 10 & $\hat{\delta}$ & 8 & & 18 & 35.5 \\
\hline 11 & $\hat{\delta}$ & 8 & & 18 & 35.3 \\
\hline 12 & 우 & 8 & & 18 & 28.2 \\
\hline 13 & 우 & 8 & & 18 & 30.0 \\
\hline 14 & 우 & 8. & & 18 & 35.0 \\
\hline 15 & $\hat{o}$ & 8 & & 18 & 45.0 \\
\hline 16 & $\hat{\delta}$ & 15 & & 32 & 45.0 \\
\hline 17 & $\hat{\delta}$ & 15 & & 32 & 35.0 \\
\hline 18 & 우 & 15 & & 32 & 30.0 \\
\hline 19 & 우 & 15 & & 32 & 33.0 \\
\hline 20 & $\hat{\delta}$ & 28 & & 69 & 41.8 \\
\hline 21 & $\hat{\delta}$ & 28 & & 69 & 40.8 \\
\hline 22 & 우 & 33 & & 78 & 29.3 \\
\hline 23 & 우 & 33 & & 78 & 33.8 \\
\hline 24 & 우 & 50 & & 114 & 32.6 \\
\hline 25 & 우 & 50 & & 114 & 32.0 \\
\hline 26 & $\hat{o}$ & 60 & & 141 & 45.2 \\
\hline 27 & $\hat{\delta}$ & 60 & & 141 & 42.8 \\
\hline 28 & $\hat{\delta}$ & 65 & & 148 & 37.7 \\
\hline 29 & $\hat{\delta}$ & 68 & & 158 & 48.0 \\
\hline 30 & $\hat{\delta}$ & 87 & & 203 & 36.7 \\
\hline 31 & $\hat{0}$ & 87 & & 203 & 38.5 \\
\hline 32 & 우 & 93 & & 218 & 32.5 \\
\hline 33 & $\hat{o}$ & 95 & & 220 & 41.6 \\
\hline 34 & $\hat{o}$ & 98 & & 229 & 41.5 \\
\hline 35 & $\hat{\delta}$ & 83 & 4 & 231 & 48.0 \\
\hline 36 & $\hat{\delta}$ & 83 & 5 & 243 & 37.0 \\
\hline 37 & $\hat{0}$ & 83 & 5 & 243 & 40.0 \\
\hline 38 & $\hat{0}$ & 83 & 5 & 248 & 39.6 \\
\hline 39 & 응 & 83 & 8 & 257 & 39.5 \\
\hline 40 & 우 & 105 & 8 & 301 & 32.5 \\
\hline 41 & 우 & 105 & 10 & 301 & 28.2 \\
\hline
\end{tabular}

* 四塩化炭素ガス吸入操作回数

** 四塩化炭素ガス吸入最終操作後の期間

*** 第 1 回四塩化炭素ガス吸入操作より屠殺までの期間 
第 2 表 旰星細胞内色素の組織化学的性状

\begin{tabular}{|c|c|c|c|c|}
\hline 実 験 動 物 群 & 第 I 群 & 第 II 群 & 第 III 群 & 第 IV 群 \\
\hline 物 番 号 & $8 \sim 15$ & $16 \sim 23$ & $24 \sim 34$ & $35 \sim 41$ \\
\hline 実 験 期 間 (日) & $10 \sim 18$ & $32 \sim 78$ & $114 \sim 229$ & $231 \sim 315$ \\
\hline 色 & & & & \\
\hline ベルリン青反応 & $H$ & $+\sim H$ & $+\sim H$ & + \\
\hline ズダンIII染色（パラフィン切片） & $-\sim+$ & + & $H$ & H \\
\hline ロイコ・マラカイトグリーン染色 & $-\sim \div$ & + & $H$ & $H$ \\
\hline $0.02 \%$ ナイル青硫酸塩 (pH2.7) 染色 & $-\sim \div$ & + & $H$ & $H$ \\
\hline
\end{tabular}

を用い, Porter-Blum MT-II 型 Ultramicrotome $に$ て作製.これら切片に電子染色を施さず（セロイド色素 とフェリチンないし血鉄素の存在様式の観察を容易にす るため), 透過型電子顕微鏡（HU-12, HS-8）にて直 接倍率 2,000〜 50,000で観察, 写真撮影を行なった.

なお，固定法において $4{ }^{\circ} \mathrm{C}, 1 \%$ オスミウム酸水溶液 （pH7.4）による単独固定 ( 2 時間) や $4{ }^{\circ} \mathrm{C}, 2 \%$ $2 \%$ グ 一ル・フルデヒド固定液 (pH 7.4) による単独固定を行 なったものについて観察したものもある。

また必要に応じて酶酸ウラニウム・硝酸鉛による電子 染色を施した切片についてひ観察した。

【方法 II】へモジデリン除去法 ( $\left.\mathrm{Lillie}^{46)}\right)$ の電子 顕微鏡観察への応用 ${ }^{50)}$.

1）前固定：摘出した肝蔵の細切片を $4{ }^{\circ} \mathrm{C}, 2 \%$ 2 ダルタ ール・アルデヒド固定夜（pH 7.4）で 2 時間固定したの ち一晚洗滌.

2）鉄除去操作：固定組織片の凍結切片（約 $30 \mu$ )を作 製し, 前田らのへモジデリン除去法50) 施行 $[0.2 \mathrm{M}$ 酢 酸塩䌅衝液で $\mathrm{pH} 4.5$ 亿調製された $1 \%$ 互二チオン酸水

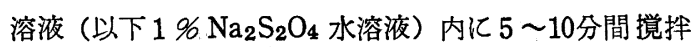
しながら浸漬後, $0.2 \mathrm{M}$ 酢酸塩緩衝腋（pH 4.5）で 2 3 回洗涤し, 続いて再蒸留水流分洗滌了.

3) Perls 法にてへモジデリンが除去されたことを確か めたのち, $4{ }^{\circ} \mathrm{C}, 1 \%$ オスミウム酸水溶液 $(\mathrm{pH} 7.4)$ で 後固定, 以下眖水・エポン包埋・超薄切片作製 (方法I と同様).

4 ) 電子染色を施さずに切片を電子顕微鏡にて観察.

【方法 III】光学顕微鏡による観察法.

摘出した䀒蔵の一部（方法IおよびIに用いた残りの 組織) の小片を10\%中性ホルマリン固定（3〜7日間） し, バラフィン切片としたものに, 以下に述べる染色法 ならびに証明法を施した。
1. 一マトキシリン・エオジン染色.

2. 過沃素酸・Schiff (PAS) 反応.

3. ベルリン青 (鉄) 反応.

4. ズダン正染色 (パラフィン切片).

5. ズダン・ブラックB染色 (パラフィン切片).

6. $0.02 \%$ ナル青硫酸塩 $(\mathrm{pH} 2.7)$ 染色.

7. ロイコ・マラカイトグリーン染色.

8. アルデヒド・フクシン染色.

9. ベルリン青反応十ズダンIII染色（パラフィン切 片)*.

また上記方法で作製したパラフィン切片を眖パラ後, 無䖝光グリセリンで封入した 無染色切片を螢光顕徽鏡 （オリンパスーFLM）による自家螢光 (Fig. 3.）の観 察もおこなった。

\section{III. 実駼 成縝}

$\mathrm{CCl}_{4}$ ガス吸入中毒マウス（41頭）䀒蔵に出現する色 素所見を, 星細胞内セロイド色素の生成過程を中心とし て述べるに光顕的にはセロイド色素は $\mathrm{CCl}_{4}$ ガス 5 回吸 入後に弱陽性に認められるようになったので $\left(\mathrm{CCl}_{4}\right.$ ガ 不吸入回数 1 回 : 4 頭, 同 2 回 : 2 頭, 同 3 回 : 1 頭忚 全例セロイド色素陰性一第 1 表参照), 以後吸入回数105 回に達するまでの34頭（動物番号：8～41一星細胞内セ ロイド色素は全例陽性）を研究材料とした。

その際ほとんどの例に血鉄素の星細胞内共存がその量 の多少に拘らず認められ, 両色素の病理発生上の密接な 相関々係の存在が推定されるのでこの点に就て検索を行 なった。

Fig.1.は $\mathrm{CCl}_{4}$ ガス65回吸入（実験期間148日）のマ

* 血鉄素とセロイド色素の同一 Kupffer 細胞内共存状 態を観察するため. 
ウス䀒において黄褐色のセロイド色素と一モジデリン (Fig. 2.) で充满された腫大星細胞内に $2 \sim 3$ 個のエオ ジンに濃染する赤血球が含まれている像を示している。 上記所見はセロイド色素の成因と赤血球との密接な関係 を示唆して㧍るもので, この種のセロイド色素は恐らく 赤血球ないしはその破片恐らく赤血球基質の肝星細胞内 貪喰の結果生成されたという想定を根拠ずける所見であ ると言える.その実験的根拠は大和 ${ }^{86)}$ によって行なわ れている（考按の項で叙述）し，さきに Hamper123） は ヒト mastopathia の出血部位に於てこれと類似の所見 を観察してセロイド色素（氏のいわゆる Fluorocyten） と赤血球との密接な関係を想定している.なおこの際大 喰細胞内にへモジデリン顆粒が遂に見出されなかった点 に関しては破砕赤血球のへモグロビン鉄より転化され た多量のフェリチン粒子が pinocytosis により大喰細 胞のライソゾーム内に活発に取り込まれると考えられて いるにも拘らず, 本粒子はその後急速に細胞外に排除さ れるために電顕的にはフェリチン粒子の集合体ないし siderosome として示されるへモジデリン顆粒が大喰細 胞胞体内に於て形成されるに至らないと理解される。

次に本実験の肝星細胞内に領喰された赤血球の種々の 崩壊段階の電顕像を示すこととする．セロイド色素顆粒 で充満された星細胞に赤血球が取り囲まれ，貪喰されつ つある像 (Fig. 4.) や一層の膜で取り囲まれた均質で electron dense な類円形物質すなわち食喰された直後 の赤血球像（Fig. 5.），また貪喰された赤血球の崩壊像 として溶血し，その電子密度の明るい stroma に 50〜 $80 \AA$ の高電子密度粒子 (ferritin-like particle) が湖 漫性にみとめられるもの (Fig. 6.)，膜様構造物をもち， 玟紋状を示す顆粒状崩壊像 (Zeligs ${ }^{87)}$ ) (Fig. 10.) や均質な stroma 内にフェリチンの集簇や空胞をむつ もの (Fig. 7.) がみとめられた. さらに後述するごと く siderosome や肝星細胞基質内に浮遊するがごとく 屚漫性に存在するフェリチンや限界膜をむたないフェリ チンの集簇像など，このような所見が実験初期から末期 に至る全経過においてみとめられた。

Kupffer 細胞は腫大した胞体に類円形，ときに不規則 な凹凸を示す核をもち, 胞体内小器官は多数のライソゾ 一ムならびに貪喰空胞, 小空胞や発達した Golgi 装置 により特徴づけられ，旺盛な 貪喰能をもつ細胞である 33）58）と一般に理解されている.このことより本実験に みられるように多数の phagolysosome をひつ腫大した 細胞（時として種々の崩壊過程にある赤血球をむつ細 胞）を Kupffer 細胞として記載した。

次に $\mathrm{CCl}_{4}$ ガス吸入回数に応じてマウス肝星細胞内に
出現するセロイド色素ならびにこれと共存する血鉄素の 超微形態像を $\mathrm{CCl}_{4}$ ガス吸入回数とセロイド色素生成状 態に基づいて, 第 I 群（動物番号 : 8〜15), 第II群（同 : 16〜23), 第正群（同: 24〜34)，そして $\mathrm{CCl}_{4}$ ガス吸入 操作中止後, 数週間正常飼育状態に放置した第IV群（同 : 35〜41）の 4つの実験群に分け，順次示す．この際と く酒色素が osmiophiliaを有し，その中でも血鉄素は 重金属としてそれ自体がかなり強い electron density を有しており，組織ないし細胞成分の超微構造をある程 度無視できる場合はグルタール・アルデヒドーオスミウ ム固定は勿論, グルタール・アルデヒド単独固定です血 鉄素を電顕的に認め得たので（セロイド色素は electron density を示さない)，本実験では両色素の動態を成る ベく選択的に観察する目的で固定法としてグルタール・ フルデヒド固定に続くオスミウム後固定法とグルタール ・アルデヒド単独固定法を使用した，原則として酢酸ウ ラニウム・硝酸鉛の電子染色を行わず，必要に応じて実 験材料ならびに実験方法の項の方法IIで示されている 1 $96 \mathrm{Na}_{2} \mathrm{~S}_{2} \mathrm{O}_{4}$ 水溶液による鉄除去法 ${ }^{50)}$ を施行した切片を 併用することによって以下述べるような両色素の共存に 関する種々の電顕上の新しい知見を得ることができたの で，以下これを順を追って示すこととする。

実験動物第 I 群 (動物番号 : 8～15).

$\mathrm{CCl}_{4}$ ガス吸入回数：5〜8回，実験期間：10１8日. マウス肝蔵の星細胞内黄褐色々素は, 鉄反応陽性色素 （血鉄素）が大部分を占めており，ごく一部にズダンIII 染色 (パラフィン切片) で陽性を示す色素が認められた (第 2 表).

この時期の電顕的観察で注 (Fig. 6. 8.), 星細胞は 長短様々な細胞突起を出し, 細胞辺縁凹凸不整であり, 核は陥凹のある不整な棈円形ないし類円形であり，広い 細胞質には大小の phagolysosomeを有し，類洞内に浮 遊していた．以下セロイド色素の超微形態を示す。

黄褐色々素含有星細胞内 phagolysosome を観察す ると (Fig. 8. 9.)，1）数少ない類円形オスミウム親 和性小体 (rounded osmiophilic body : rOB) やオス ミウム親和性顆粒（osmiophilic granule : OG）を辺 緑部に，そしてそれらの間隙を埋めるようにオスミウ 么親和性の低い均質無構造な 不定形物質 (low osmiophilic amorphous material : LOAM) が内部に存在 するが,フェリチン様粒子を認めない phagolysosome. 2 ）辺縁部に rOB と OG，そして内部の LOAM の占め る部位と同部位にフェリチン様粒子をみとめる phagolysosome. 3 ) rOB や OGが存在せず, LOAMとフェリ チン様粒子からなる phagolysosome. 4) rOB, OG, 
LOAM やフェリチン様䊉子の注か，不規則な走行を示 す少量の膜様構造物をるつ phagolysosome などがみ られ，それら phagolysosome の大半が類円形であり， 比較的簡単な構造からなるものであったが，ごく稀に上 記 phagolysosome が数個融合することにより形成され たと思われる辺縁凹凸不整で大きな phagolysosome む みられる。

これら phagolysosome の内部構成要素の rOB の存 在様式に特異なるのがみられた。すすなわちこれら roB は phagolysosome の辺縁部存在するものが多くみ られ，しかも未だ細胞質基質内にその一部を留めている 状態 (rOB が phagolysosome と部分的に融合した状 態で細胞質基質へ突出した形態を示す）の rOB るみら れた (Fig. 9-c.)，また phagolysosome と融合するこ となく細胞質基質内に遊離, 浮遊している $\mathrm{rOB}$ る れた（Fig. 9-c.）（これらの電顕像は細胞外より星細 胞内へ領喰された物質, この場合 rOBが phagolysosome と融 合し, phagolysosome で処理される過程の 一時期を示しているものであり，細胞質基質に浮遊して いる rOBに比して phagolysosome と一部分が融合し た rOB の存在様式を示すものが 多いのは, 貪喰処理過 程俉要する時間的差異によるものと考える). フェリチ ン様粒子の存在様式は，種々のオスミウム親 和性物質 をもつ phagolysosome 内の LOAM によって占拠され ている部位と同部位にび漫性に存在するるの (Fig. 9b.）や siderosome の形のひのがあるほか，細胞質基 質澓在性または集簇性（限界膜を形成するに至ってい ない)に存在するすのむみとめられた (Fig. 9-a.).

実軮動物第 II 群（動物番号：16２3）

$\mathrm{CCl}_{4}$ ガス吸入回数 : 15〜33回，実験期間 : 36〜78 日.

マウス肝嵗は既存の構造が破壊され，グ氏鞘を中心と する線維増生が不規則におこり，一部に偦小葉の形成も みられた。しかも黄褐色々素顆粒を胞体内にるつ星細胞 がグ氏鞘およびその周囲の線維増生領域に多数みとめら れた。それら星細胞内黄褐色々素はズダンIII染色（パラ フィン切片), ロイコ・マラカイトグリーン染色, 0.02 \%ナイル青硫酸塩（pH 2.7）染色により陽性所見を示す 色素と鉄反応陽性色素より成っていた。すなわちセロイ ド色素と血鉄素が同一星細胞胞体内に共存していた（第 2 表).

この時期の電顕的観察では, 黄褐色々素含有星細胞の 胞体には辺縁凹凸不整, 大小様々な phagolysosome が 多数みとめられた (Fig.10.).これら phagolysosome は，比較的簡単な内部構造の phagolysosome（実験第
I群で主にみられたもの）が数個互いに融合することに より形成されており，多くの類円形オスミウム親和性小 体（rOB）やオスミウム親和性 顆粒 (OG) を含有して いる.

これら phagolysosome の構成要素の rOBが, phagolysosome の辺縁部ではなく，より内部に存在する ようになり (Fig. 10.)，しかもそれら rOBが互いに融 合している像や融合しつつある像もみとめられるように なった (Fig.11-a.).フェリチン様粒子の phagolysosome 内の存在様式に少し変化がみられるようになった 状態，すなわち種々のオスミウム親和性物質の小集簇の 間隙や phagolysosome の辺緑の狭い部分（殆んどオス ミウム親和性をむたない部分）にフェリチン様粒子が高 密度に存在する状態がみられる (Fig.11-a.)。また一 層の限界膜を伴うフェリチン様粒子の集簇が発芽するか のような形態をとりながら phagolysosome から 細胞 質基質へとび出そうとしているすのや，とび出した後に 生じたと思われる siderosome るみられた (Fig.11-b., 12.). 細胞質基質内に散在するフェリチン様粒子に関し ては 実験第IV群で後述するように同粒子の phagolysosomよりの排出に由来する場合も考えられる。

実験動物第吕群（動物番号 : 24 34）

$\mathrm{CCl}_{4}$ ガス吸入回数：50〜98回，実験期間：114〜 229日.

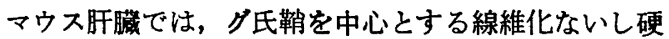
变が進行し，またエオジン好性を示す凝固壊死肝細胞も その領域付近にみられた. しかも線維化巣（とくにグ氏 鞘周辺部) に法黄褐色々素を胞体全体にもつ畽大した星 細胞が多くみられた。

それら黄褐色々素の性質は，実験動物第群とほほ同 様セロイド色素と血鉄素から成っていた（第 2 表).

この時期の黄褐色々素含有星細胞の電顕的観察では, 大小浱淡および形態様々なオスミウム親和性を示す（あ るいは電子密度）物質を高密度にもつ大小様々な pha一 golysosome が多数みとめられた (Fig. 13.14.15.). とくに第群と異なった所見としては, rOBが融合する ことにより形成された辺縁不整なオスミウム親和性物質 が増加したこと,またそれら rOB や辺縁不整なオスミ ウム親和性物質の内部に高度オスミウム親和性均質で緑 取られた殆んどオスミウム親和性を示さない空胞をるつ 親和性小体 (Fig.14) 〔osmiophilic multivacuolar structure（後述）の前段階の物質了あみられるように なった.

フェリチン様粒子は phagolysosome 内では減少 し, phagolysosome の辺縁部の限界膜直下の狭い部位 
そみとめられるのみである (Fig. 14.)，細胞質基質内 には集簇性あるいは散在性のフェリチン様粒子がみられ るが，第II群と同様の意義が考えられる。

実験動物第IV群（動物番号：35～41）

$\mathrm{CC}_{4}$ ガス吸入回数：83 105回, 最終吸入操作後 4 〜10週間正常飼育したもの. 実験期間：231～315日. マウス肝臓では, 既存の細胞構築が乱れ，しかるグ氏 鞘周辺には大量の黄褐色々素顆粒で充満された星細胞が 多数存在するが, 第正群のマウス盰䁍に比して線維化巣 の領域は狭小化し，乙かもその領域に洗固壊死肝細胞 がみとめられなかった。

星細胞内黄褐色々素は, ズダン亚染色（パラフィン切 片)、ロイコ・マラカイトグリーン染色， 0.02\%ナイル ブルー硫酸塩（pH 2.7）染色など, いずれの染色にも強 陽性を示すセロイド色素が大部分を占めており，鉄反応 陽性色素（へモジデリン）の割合が減少している（第 2 表).

この時期の黄褐色セロイド色素含有星細胞の電顕的観 察では，多種多様な形態を示し，種々のオスミウム親和 性物質を高密度に有する phagolysosome が胞体全体 を占め，核は偏在していた（Fig. 16.17.18.19.20.).

これら大小様々しかも辺縁凹凸不整な形態の phagolysosome は次のような種々の物質 [(1)〜(9)]を含有し ていた.すなわち(1)高度オスミウム親和性物質により縁 取られた大小の空胞 (electron translucent vacuole with high osmiophilic peripheral rim)を多数もつ 大小のオスミウム親和性小体（オスミウム親和性多空胞 性構造物 : osmiophilic multivacuolar structure) (Fig.18.20.), (2) electron translucent vacuole 1 個しかもたないオスミウム親和性小体，（3）濃淡様々 不均質で奇 怪な形のオスミウム親和性物質 (bizzare osmiophilic material)〔次の(4)の物質が互いに融合 することにより形成された物質と思われる」，(4)大小様 々な類円形のオスミウム親和性小体 (rOB)，(5) オスミ ウム親和性顆粒 (OG)，（6）不規則な走行を示す膜様構 造物 (membranous structure), (7) osmiophilic fingerprint-like structure : 渦巻状層状構造をむつ オスミウム親和性小体（Fig.19.)，（8）低オスミウム親 和性不定形物質 (LOAM), (9) フェリチン様粒子（少 量かまた殆んどみとめられない). この時期の phagolysosome の内部には，種々のオスミウム親和性物質が 高密度に存在するようになり, しかも osmiophilic multivacuolar structure など(1)〜(3)の物質が多く みられるようになった (Fig. 18.20.)。杂に反して LOAM が phagolysosome 内で占める領域は狭小化し，
しかもフェリチン様粒子はこのような部位では殆えど みとめられなくなったが，細胞質基質内にはみとめられ る (Fig. 20.21.22.23.). このことはグルタールアル デヒド単独固定切片の電顕的観察でもあきらかである (Fig.24.).しかし細胞質基質内のフェリチン様粒子量 は phagolysosome 内のフェリチン様粒子が減少したに もかかわらず, 実験動物第 I・II・III群の星細胞の細胞質 基質内における存在量と実験動物第IV群との差はほとん どみとめられず，細胞外への排出が考えられる.

このように $\mathrm{CCl}_{4}$ ガス吸入回数が著しく多く, 実験期 間が長くなると, 星細胞のセロイド色素の沈着量に反比 例して共存血鉄素の沈着量が一見減少しているが，この 所見の説明として，フェリチン粒子の lysosomeによる 運搬・排泄の過程が絶えず一定のリズムで行われている ほか, セロイド色素顆粒のようなフェリチンに比して著 るしく排泄され難い色素顆粒の lysosome 内に和ける 蓄積が lysosome 内のフェリチン出現を抑制しているこ とに基うくと考えられる. また実験動物第IV群のように $\mathrm{CCl}_{4}$ ガス吸入操作を中止したのち長期放置した場合に 就てみるに，フェリチン生成の材料である赤血球（ない しへモグロビン) 貪喰現象がほとえど行なわれないため 無処置の放置期間の間に lysosome 内に含まれていた 物質が消化・処理される過程で生成されたセロイド色素 は排泄されず，蓄積されたままであるのに対して，フェ リチン粒子怯その生成があまり行われないにもかかわら ず, lysosome からの排除が絶えず行われるため 1ysosome 内にほとんどみられなくなると考えられる。

方法IIによる成績： $\mathrm{CCl}_{4}$ ガスを吸入させたマウス旰 臓内の黄褐色々素含有星細胞を電顕的に観察すると細胞 質基質および phagolysosome内に多量のフェリチン様 粒子をみとめ，光顕的にも鉄反応陽性を示す物質をみと めたことは既述したが，組織化学的にフェリチンないし へモジデリンであることを確認するため方法II の鉄除去 方法50)を電顕レベルで用いた。

その結果, 旰星細胞内のフェリチン様粒子は細胞質 基質内に散在したものや集簇していたものはもちろん phagolysosome 内に存在したものも含めて, これら全 てが完全に消失したが (Fig. 25.)，この際同処置の切片 が光顕的にも鉄反応は陰性化するのを確かめている.し かしこのようにフェリチン様粒子が消失したphagolysosome の基質は依然ある程度の濔漫性の low electron densityを保っているのが鉄除去後に反って比較的明瞭 に認められるようになったが，この所見はへモジデリン の基質をなしている一種の 糖蛋白質 21 ) の存在を電顕的 に示しているものと思われる50)。 


\section{IV. 考按}

セロイド色素ないしリポフスチンとへモジデリンある いはジデリンが同一大喰細胞内に共存する所見より，上 記両種の色素の生成過程を関連づけて観察した報告は光 顕的なものはへモクロマトージスの症例を別とすれば若 干18) 19) 74) みられる程 度で, 電顕による業蹟に就てる Sorenson ${ }^{73)}$, Miyawaki ${ }^{56)}$, Bessis4) 等の報告が散 見されるに過ぎない。

この内, 光顕的な報告をみるに Spicer ${ }^{74)}$ は老齢マウ スに就て頸部リンパ節, 脾, 腸管の大喰細胞内に血鉄素 と共存するリポフスチン（氏の言うリポフスチンはこの 場合セロイド色素とみなした方が良いかも知れない）の 存在を述ベ, 同時に肥胖細胞の増生にも注意をしている が，上記所見の出現機構に就てはあまり触れておらな W.

さきに Hamper123) は卵巣テール囊胞壁, 輸卵管血腫 部位, マストパチー乳腺の衰腫等に認められる大量のセ ロイド色素が常に小出血巣と接している所見に基づいて この種のセロイド色素が赤血球の崩壊産物の大喰細胞に よる領喰の結果生成されることを推定したが, その直接 の根拠となる組織像を呈示していない. Hartroft 26) や Casselman $^{6)}$ はセロイド色素の生成関する赤血球の 役割を in vitro の実験結果からセロイド色素の素材と いうよりはセロイド色素生成の触媒物質として評価した が, 続いて Hartroft ${ }^{27)}$ はヒ ョリン欠乏食で飼育するこ とによって生じさせたラットの脂肪肝の脂肪性囊胞が破 綻してその内腔が赤血球で満たされたものはパラフィン 切片・ズダン好性を獲得して赤血球の破片や赤血球とほ ほ同一の大きさのセロイド色素塊を含むに到っているの を観察した。 さらに Porta ${ }^{60)}$ は赤血球を肝油等の不飽 和脂肪に混じた混合物を $37^{\circ} \mathrm{C} て ゙$ 数日間放置したものから パラフィン切片を作製し, oil red O 染色法や䝁光顕微 鏡検査から in vitro で变性赤血球内にセロイド色素形 成を見出し, 他方上記放置期日 6 日のものについて電顕 観察を行ない, 变性赤血球内に於て七ロイド色素顆粒に 相当する dense body の形成を phagosome 内に認め たが，この点は赤血球のセロイド色素生成における意義 を立証しているものと言える.その後リンパ節大喰細胞 におけるセロイド色素と血鉄素の共存所見の出現機構に 関して前田 ${ }^{49)}$ ，大和 ${ }^{86)}$ はこれを大喰細胞による赤血球 基質の貪喰現象と関連ゔける光顕レベルでの実験に成功 している.

著者も本実験の成績が示すように実験初期より末期に 至る $\mathrm{CCl}_{4}$ 中毒マウス肝星細胞胞体内に種々の段階の被
貪喰赤血球の崩壊像を見出すととができた．近藤ら43) は脾大喰細胞内の被食喰赤血球の崩壊過程を 3 種類の過 程, 寸なわち第 1 型一被貪喰赤血球が分岐・細分される 分岐崩壊型，第 2 型一余り分岐・細分されない非分岐崩 壊型, 第 3 型一被貪喰赤血球の内容が空胞化する型があ ると述べている.Zeligs ら ${ }^{87)}$ は甲状腺ろ胞上皮細胞内 の赤血球崩壊過程を顆粒状崩壤過程と溶血崩壊過程に分 類し, 両過程とも ferritin-like particle が最初にみ とめられるのは細胞質基質であり，その後 lysosome に集中するようになると述べている，Marton51) は骨 髄細網細胞における erythrophagocytosis において貪 飲した赤血球を含む initial phagocytic vacuole と lysosome が融合して形成された digestive vacuole内 で，その消化の初期には電子密度の低い赤血球基質内に ミェリン様構造物や斑紋状構造物がみられ，最終時には その空胞が縮小し, secondary lysosomeになると述べ, またフェリチン粒子の細胞内出現量浾䖝球貪喰現象の 程度にほほ平行すると述べている. Collet や Petrik7) 59) らはまず血液の 気管内注入後 2 時間の短期実験を行 なったが，既にその際肺胞大喰細胞における被荟喰赤血 球内に貪喰空胞や結晶様構造が出現するのを認め, つい で肺胞大喰細胞内被貪喰赤血球の48時間に亘る消化過程 を観察し，これを溶血過程（4段階）とへモグロビン消 化過程 (3 段階) に分けて詳述し，フェリチンが出現す るのはへモグロビンが消化された時, すなわち赤血球が 完全に崩壊した時点であるとしており，Fedorkoら 14) も Collet らの意見を裹付けるように腸間膜リンパ節大 喰細胞内に赤 血球が完全に崩壊した時点であるとして いる.すなわち. Fedorko ら 14) は腸間膜リンパ節大喰 細胞内に赤血球を貪喰させたのち，2 日目で胞体内に プルシナンブルー反応陽性物質をみとめ, その時期に lysosome 内にフェリチンが存在するようになると述 ベている. Edwards ら11) も正常脾大喰細胞内におい て赤血球崩壊の末期に ferritin が phagosome より 細胞質へ排出されるとしている．また赤血球貪喰現象 に関して Heinz body anemia1)65) を始めとして数多 くの超微形態的報告21２2）57６7）70７5８4）88）がみられ る.

本実験の Fig.4. やFig. 5. にみられる赤血球貪喰像 は Stoekenius ${ }^{76)}$ のいう赤血球崩壊過程の初期像ある いは Marton ${ }^{51)}$ のいう initial phagocytic vacuole ないし digestive vacuole への移行期の像に相当し,

Fig.6.にみられる赤血球貪喰像は Petrik ら59)のいう へモグロビン消化終了時の像あるいは近藤ら43) の非分 岐崩壊型の一過程を示す像に相当し, Fig. 8. や Fig. 
10.にみられる被荟喰赤血球像は Zeligs ${ }^{87)}$ のいう顆粒 状崩壊過程の一時期を示す像に相当する. そして実験初 期にみられるフェリチン様粒子や少数の rOB や OGそ して膜様構造物を有する小さな phagolysosomeの多く は分岐崩壊型43) の末期にあてはまるすのと思われる. Stoekenius ${ }^{76)}$ は脾大喰細胞に貣喰された赤血球崩壊過 程においてフェリチンおよびへモジデリンとミェリン様 構造物とが出現することを報告しており，Bessis ら4) も光顕的観察に際して貣喰赤血球破片周囲に一モジデリ ン顆粒の出現と共に PAS 反応陽性，ズダンブラック染 色陽性を呈することもあると述べ, 電顕所見ではフェリ チン粒子の濃厚な集塊と共に恐らくズダンブラック陽性 物質に該当すると思われるミエリン様構造物を見出して いる. 近藤 ${ }^{43)}$, Petrik ${ }^{59)}$, Marton51) らもミエリン様 構造や脂質様電子密度小体をみとめているが，フェリチ ン粒子ないしへモジデリン顆粒と共存する上記物質がセ ロイド色素である可能性も多分にあるのではないかと思 われる. 次にライソゾームによるフェリチン粒子の運搬 は肝細胞に就てみると，そのライソゾーム (secondary lysosome) によるフェリチン粒子の reverse pinocytosis による細胆管腔内への排出経路が Bradford ら5) により示されている. また Trumpら81) はフェリチン 粒子を有する secondary lysosome が細胞膜と融合す ることによりフェリチン粒子はその細胞膜を通過して細 胞外に排出されると述べている。

一般に赤血球捕捉機構（sequestration）に関しては 䀒が脾と並えで大きな役割を果すことが知られており， Schmidt ${ }^{67)}$ 海無処置マウス肝星細胞に就て超微構造的 に赤血球貪喰像を示している. この機構には赤血球の側 からみた場合, 赤血球膜の障害すなわち赤血球膜に生じ た化学的変化が膜の粘着性, 弾性, 荷電状態など膜の物 理・化学的性状にかなりの変化を生じること ${ }^{79)}$ が脾に おける赤血球捕捉の要因としてあげられている。また Smith ${ }^{71)}$ によるとヒトリンパ節に関しては erythrophagocytosis が疾患や輸血の有無に拘らず75\%の高率 に見出され，しかもその際しばしば血鉄素の出現を伴う ほか,，本現象の要因として不明確な点はあるものの赤血 球の変性のほか, リンパ洞壁を構成する細網内皮ないし 細網細胞の肥大・増殖で表わされる荟喰能の六進があけ られている.

他方, 赤血球の類洞通過が肝に比して困難とみられる 脾における赤血球捕捉の要因となっている赤血球停滞現 象 25) (erythrostasis) が本実験に於て $\mathrm{CCl}_{4}$ 中毒肝の とくに強く障害されている小葉中心部の中心静脈とこれ に連なる類洞に生じているとみられる28).このような
状況から斉らされる Kupffer 細胞内フェリチン， へモ ジデリンの出現は erythrophagocytosis の要素をセ口 イド色素の生成要因としての面より重視する必要がある ことを窺わせるものである。

赤血球捕捉は赤血球貣喰という形態的所見によって認 め得るが, その機構として大喰細胞が被貪喰老化赤血球 にまず付着し82), 次いで赤血球をそのまま（フェニー ルヒドラジン処理によって得られる Heinz 小体含有1) 65)）あるいは赤血球の断片化したもの12) をそのライソ ゾーム（酸性フォスファターゼ陽性 ${ }^{12)}$ ) 内に取り込む にせよ, 赤血球の捕捉後, 僅か 1 時間位で血中の間接ビ リルビンの上昇が認められること ${ }^{35}$ や赤血球食喰現象 に伴う被領喰赤血球の溶血過程が始まってから6時間程 の間に一モグロビン鉄はへモグロビンからはずされ，さ らに食喰細胞から逸出し，血中 transferrinと結合して 骨髄内に運搬され，そこでこのものがへモグロビンの新 生に再び利用される事実 ${ }^{36)}$ や Bessis の erythrophagocytosis の過程が 5 15分間という記載3)などはいゔ れも赤血球処理過程がかなり短時間の間に行なわれるこ とを意味する.それと共に，䀒網内系もかなりの程度障 害された赤血球の処理に関しては脾以上に関与するもの とみられるものである。例えば一定時間の熱処理や Nethyl-maleimide によって変性に䢴らしめた赤血球の 大部分は旰網内系で 抑留されることが $\mathrm{Cr}^{51}$ でラベルし た赤血球のラジオ・オートグラフィーによって示されて いる83).

扱，再びセロイド色素，鉄の共存所見に就て述べるに Golberg ら 18) は高脂肪食慨による飼育に加えてデキス トラン鉄の筋注処置の併用を行なったラット群の盰（大 喰細胞)，腎（細尿管上皮）に於て組織の自己融解像，鉄， セロイド色素の出現というビタミン $\mathrm{E}$ 欠乏食餌飼育ラッ トに共通する病変を認めたと述べ，次いで（1960年19)） エチオニン含有蛋白欠乏食餌投与とデキストラン 鉄筋 注併用群の硬変に樎った肝に就てセロイド色素と鉄の Kupffer 細胞内共存所見を示している．この場合の鉄が 血鉄素ではないところに問題があるにせよ Golberg ら 19) によると䀒内で 鉄と共存するセロイド色素性鉄（デ キストラン鉄）の過剩投与のみでは出現せず，これにェ チオニン含有蛋白欠乏食餌のような肝障害性食慨飼育の 方法を併用することによって始めてセロイド色素が出現 するのである.この点からセロイド色素の出現機構とし て，まず肝障害の組織所見として肝細胞内脂肪ことに不 飽和脂肪の出現, ビタミンEのような組織における抗酸 化作用物質の欠乏, 䀒実質ことに恐らくミトコンドリア の障害があるところに細胞内に過剩に沈着した鉄の触媒 
によってセロイド色素が形成される機序が考えられてい る.

次に，セロイド色素とへモジデリン顆粒との共存所見 に関する電顕的報告に就てみるに, Miyawaki ${ }^{58)}$ は処 女並びに経産マウスの乳腺の腺上皮内に見出される鉄反 応陽性色素は単なる血鉄素ではなく，超微形態的にはフ エリチン粒子の集合体（へモジデリン顆粒）とリボフス チンの構成成分を示す数多くの多形性の dense body や層状ないし膜梯構造物より成っていることを示してい る. Sorenson73) は sideroblastic anemia 患者の骨 髄大哴細胞の超微形態像としてへモジデリン顆粒とみな されるフェリチン粒子の集合体がセロイド色素に相当す るとみなされる多数の空胞含有 dense body と共存す る所見を示している.

ここでへモクロマトージスの症例に就てみるに，へモ ジデリンと共存するへモフスチン（hemofuscin）をそ の命名者である von Recklinghausen が鉄反応陰性の 血性色素の一種とみなした皇のに続いて Sheldon ${ }^{88)}$ は 本色素をメラニングループの一種であるとし，Gillman ら ${ }^{16)}$ は本色素をミトコンドリア由来としているが, 本 色素を一種のリボフスチンとみなす見解9) 31)が その後 一般に行なわれたが，本色素がセロイド色素と一致する 場合32) 34) も知られている. また本色素をへモクロマト 一ジスに特異的であるとみなす48) 68) のが一般的な見解 であるが，異論91 15) 29)すなわち非特異的とする見解む みられる。

このへモフスチンの生成機転とフェリチンのそれとの 関連性に関してはへモフスチンそれ自体の意義は不明 48)かあるいはそれに触れておらず15)，これに対して Sheldon ${ }^{\text {(8) }}$ は本色素をメラニンのグループとみなす立 場よりへモフスチンの出現をメラニンの代謝異常と関連 させており，また Sheuer (506) は超微形態的にへモフ スチン顆粒が細胆管近傍に集積することを見出し，フェ リチン粒子も同じ場所に集積する傾向を認めて両色素の 密接な関連性を推定している.

Dubin $^{92}$ はへモフスチンが各蔵器の血管壁, 間質結合 組織, 消化管, 平滑筇等に沈着する傾向が強いととはり ポフスチンとの類似点であるとする立場から本色素の特 異性に懷疑的であり，へモジデリンと本色素との間の移 行を認める説にも否定的である。

井上ら ${ }^{34)}$ は Mallory のフクシン染色所見からへモ フスチンとへモジデリンとの間のある程度の移行像を認 め得たとして両色素間の密接な関連性を推定し, 伊原ら 32）によると搼外分泌腺細胞内に沈着するへモジデリン の微細顆粒はほとえど例外なく粗大なへモフスチン顆粒
のほほ中央部に見出されるので，この所見はへモフスチ ンが長期に亘って腺細胞内に沈着しているへモジデリン 顆粒を核として（ないしはへモジデリンの基質を核とし て）形成されたことを暗示しており，しかもへモフスチ ンはセロイド色素が本来大喰細胞内に形成される点では 異なっているとしてる自己拡大生産的な著しい蓄積性を 示す点ではセロイド色素と共通している。その結果, 色 素蓄積細胞では核の偏在, 不整化,ビクノーゼ等がみら れるようになり, 徐々に細胞全体の变性を来たして崩壊 する過程がみられるようにへモフスチンとへモジデリン の生成過程に切り離すことのできない関連性があり， モジデリンはそれ自体細胞障害性は少なく（単なる血鉄 素症では肝細胞の变性は少なく，線維化ないし硬变症に 至るととは通常みられない), 一モフスチンの沈着・増 量の過程を介して強い細胞障害性を発揮する一一結果と して肝・膆の硬変症を合併—ものであろうとしてい る.

しかし，上記の所説のようにへモフスチン（セロイド 色素）がいわばへモジデリンの一種の触媒作用によって 形成されるとする考えは他の報告には見当らない点や実 験的裏付けがなされていない点で更に検討の余地がある と思われる.これに対して赤血球の場合，これがセロイ ド色素の直接の素材となるという既述の見解のほか赤血 球の触媒作用で不飽和脂質よりセロイド色素（大和の脂 肪性セロイド様色素）が形成されるとする見解隹対する 幾つかの実験的裏付け6) 26) 27) はなされているが,この 場合のセロイド色素は「脂肪性セロイド様色素86)」に 限られており，真のセロイド色素の成因はさらに複雑な 機構と考えられる。

これに対して Finch ら 15) は大量のへモジデリンの沈 着の局所組織細胞に対する障害性を肯定し, 䀒線維化も その結果であろうと論じ, Smith ら ${ }^{72)}$ は過剩の鉄を含 むメジウム中の䀒薄片に於て蛋白合成の障害が生じてい ることを示している。この見解に対して MacDonald ら48) はへモジデリンの大量沈着と肝・膵の硬变症の生 成との間の関連性には懐疑的であり，Scheuer 566) ซ これと同調しており，線維化ないし硬変症の成因として へモクロマトージスの症例の環境因子，例えばフルコー ル中毒や栄養障害などとの関連性む考虑すべきであると している.

次にへモジデリンではなく，ジデリンに就ての報告を みるに, Gillman ら 17) が特に指摘している点として鉄 過剩食投与による盰血鉄素症を生成させる要件としてラ ットの食飰にはトウモロコシ食のような栄養価が低く， かつ偏った食餌を選ぶべきことがあげられ，標準固形食 
を過剩鉄と共に与えてる良い成績が得られない点に注目 している. Kent ら ${ }^{37}$ ) は $\mathrm{CCl}_{4}$ 皮下注射ラット肝 (実験 期間26日）に就てデキストラン鉄筋注による肝内鉄沈着 量の定量的成績を示しているが，その結果は無処置動物 （鉄沈着注 Kupffer 細胞内に限局）のそれと殆えど変わ らない.このことは N-2-fluorenylacetamide (FAA) やエチオニン投与ラット肝ではデキストラン鉄投与によ り肝内鉄沈着量（肝細胞内に沈着）が著増する定量的の 成績とは極めて対照的であるとしているので，少なくと も $\mathrm{CCl}_{4}$ 投与は䀒細胞の鉄親和性を增大するとは言えな い.したがってその際にみられる星細胞内血鉄素の出現 機構は上記と異ったものであるとみなされる.

次にフェリチンないし血鉄素（あるいはジデリン）の みを主題として取り扱った電顕的報告は Farrant 13) (1954), Richter ${ }^{62)}$ (1957) 以来現在までに夥しい数に 達しているので，その中で本実験成績の考察と関連する あのから年代を追って順次取りあげてゆくこととする.

まずウマ脾から分離されたフェリチンに就ては Farrant ${ }^{13)}$ はこのものは直径 $27 \AA$ の 4 つの subunit か

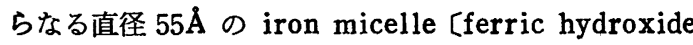
(phosphate)]とその周囲を取り囲む蛋白成分からなる 直径 $94 \AA$ のものであるといい, Kuff ら44) るラット畈に 於てフェリチンは Farrant13) の記載とほほ同様の超微 構造を示すとしている。これに引き続いて Richter ${ }^{62)}$ 63)の 報告を中心としてフェリチン粒子とへモジデリン 顆粒の超微構造上の関連性が漸次解明されるに至って, 以後後述するように関連業蹟が翌出している.

扨，Richter ${ }^{62)}$ が 1957年に行なったーモグロビンの 腹腔内注入ラットの腎細尿管上皮についての研究成續に よるとへモジデリン顆粒は直径 $55 \AA$ の高電子密度粒子 (フェリチン粒子)の集合体として認められ，エチオニン 経口投与ラット肝細胞内に見出された siderosome に関 してはミトコンドリフとの関連性が論ぜられた（後述）。 さらに Richter (1958) ${ }^{63)}$ は輸血性へモジデロージス のヒト肝細胞のーモジデリン顆粒並びにへモジデロージ スのヒト脾から作製したフェリチン結晶とを比較研究 し、フェリチン粒子はへモジデリンの一成分であり，か つへモジデリン顆粒の一部はフェリチンの結晶であると いう結論を引き出しているが，氏は翌年64)デキストラ ン鉄および saccharated iron oxide の腹腔内注入マ ウスの脾大哴細胞について上記結論を支持する所見を示 すと共に同細胞内のフェリチン粒子が注入鉄戍のジデリ ンに由来するものであることを超微形態的に検討し，こ れを立証している.

同年 (1959) Wessel ら ${ }^{85)}$ はコロイド鉄のマウスに
対する頻回の皮下注射によって生じさせた局所の肉芽腫 内大喰細胞を観察した結果, その部の siderosome の起 源としてミトコンドリアや細胞小胞体を除外し, 細胞膜 の陌凹, 水胞化酒由来する phagosome ないし phagolysosome（氏自身は明記していない）相当構造物を考 えまたジデリンの基質に相当する物質として比較的コ ントラストの薄い鉄ミセルを取り囲む物 質を示してい る.

また Bessis らは骨蹎の細網細胞内における赤血球の 消化過程に於てその胞体内の貪喰赤血球の基質に接して フェリチンの出現を見出し，このフェリチン䊉子は赤血 球領哙現象に由来するとみなし4), 別に未熟赤血球が pinocytosis の機構で鉄ミセルを大哴細胞より受け入れ ている所見を示している2)。有核赤血球へは細網細胞 よりその胞体内に於て古い赤血球の破壊により生じた 鉄ミセルに由来するフェリチン粒子が転送されると述べ 3), さらに一種の heme 合成障害性㙰血症 (hypochromic hypersideremic anemia) の網状赤血球ミトコ ンドリア内にフェリチン粒子ないし鉄ミセルの限界膜を 有しない㠜集構造の存在を示し, 正常鉄代謝にもミトコ ンドリフが関与することを示唆している3)，Zeligs87) は thiouracil $4 \sim 7$ 日間の経口投与を行なったラット 甲状腺上皮細胞の erythrophagocytosis の像として赤 血球が貪喰され，消化され，变性しつつある過程に於て フェリチン粒子が赤血球周辺から出現し，やがて 1ysosome 内に凝集し，へモジデリン顆粒として上皮細胞内 に証明されるに至る過程を示している。.またMarton52)

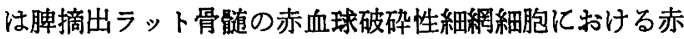
血球荟喰消化過程においてライソゾーム内でへモグロビ ン由来の鉄とてボフェリチンによりフェリチンが形成さ れ，その後の水解酵素による消化化耐えてライソゾーム 内に残存したフェリチンを密に含有するるのを siderosome と云い, lysosomal iron の変性により形成され たへモジデリンを細胞内での鉄の最終的な貯蔵形態であ るとしている.

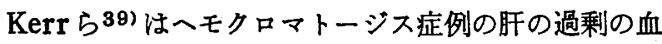
鉄素は細胞質基質にみられる多数の高電子密度粒子（直

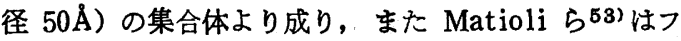
×リチンの酸化作用による変質 (ferritinic form), さらにその蛋白分解作用による変質 (non ferritinic form 一電顕レベルでフェリチン粒子の特徴的な構造が 失われている）によりへモジデリン顆粒の生成が行なわ れ，さらにその還元やあるいはキレート化によって鉄成 分がへモジデリンより放出されるとする見解を表明し， それを支持する化学的, 血清免疫学的成績や電顕所見を 
呈示している.

他方, Shoden および Sturgeon ${ }^{69)}$ は始めヒトやウ サギから得たへモジデリンの化学的分析を行ない，この ものは均質な化合物ではなく,フェリチンとは明らかに 異なるという結果を得ている．その後さらに Sturgeon ら77) 注組織内鉄分含量の多少によってフェリチン粒子 とへモジデリン顆粒とを組織化学的並びに超微形態的に 区別するととを試みて，次のような成績を得ている。す なわちウサギ肝組織100 g につき10１00mgほでの鉄含量 ではフェリチン粒子の形態を示し（フポフェリチン基質 は水溶性), プルシフンブルー反応陰性であるが，鉄含 量が組織100 g につき 150〜200mg になるとフェリチンは 微粒子とその集塊や結晶との混合形態を示し(この際〉 ボブリチン基質は変質して水難溶性になるという), プルシアンブルー反応は疑陽性となる。ささらに鉄含量が 組織 $100 \mathrm{~g}$ につき 300 1 $1500 \mathrm{mg}$ に達するとフェリチンは 集合した鉄ミセルすなわちへモジデリン顆粒となり， オ ポフェリチン基質は变性, 消失し，プルシフンプルー反 応治強陽性に現われると述べている。このように肝に於 けるフェリチン粒子は局所組織における鉄含有の増大に 伴ってへモジデリン顆粒の形態を示すが，他方フェリチ ンが変質する場合をみるにてポフェリチンが変質を生じ て水不溶性となり, 同時にその結晶性（その特有の 4 つ の subunitより成る形態）を失って凝縮し，鉄ミセル の無晶形を示すに至るが，このものは本来のへモジデリ ンかあるいは鉄含有ミセル，集合鉄ミセルと称すべきで あり，したがってへモジデリンはフェリチンの単なる集 合体とみなされるべきではないとしている（実際問題と して電顕写真では上記のようなフェリチン，へモジデリ ン両者の本質的な区分が困難な場合が 多いととは本実 験の成績で示した通りである). 他方 Sturgeon ら 77 に よると "Kupffer cell iron” は saccharate iron oxide の注射によって認められるが，その沈着の経過は 始めはフェリチン沈着に始まり, その量が正常の30倍 に達すると漸く生化学的, 組織学的に ジデリン顆粒と 確認できる.ささらに実験期間の経過と共にジデリンは Kupffer 細胞よりむしろ肝細胞に沈着し，Kupffer細胞 自身の鉄沈着量は減少するので Kupffer 細胞怯鉄の機 動的な受け渡しを行ない，これに対して肝細胞内の鉄は 一旦沈着すると，かなり安定的であるとの見解を示して いる. その際氏らも補足しているように，さらに実験期 日の進えだ時期に於ては肝細胸より放出されたとみられ る鉄を貪喰した Kupffer 細胞の鉄は安定しているので これは機動的な, 受け渡し可能な鉄とは区別されるべき であるとしている．次にフェリチンの生成部位の問題に
関しては鉄の異常代謝の場合は phagosome の関与が問 題となるとしても生理的には Klavins41) はフェリチン の合成は遊離リボゾームに於て行なわれると述べ，フェ リチン粒子は粗面小胞体の腔内ではなく，その外側に出 現する電顕像を示している.Puroら61) もこの見解を支 持して,フェリチンは遊離および膜結合性ポリゾームに より合成されるという見解を発表している。それによる とラット肝よりポリゾームに富むフラクションに就て膜 結合性ポリゾームと遊離ポリゾームとの割合を電顕的, 生化学的さらにラジオフイントープの方法を用いてチ ェックし，ラベルしたアミノ酸 (1-leucine 4.5-3H) のフェリチン蛋白（フポフェリチン）への組み入れ量 を定量的に測定し，膜結合性並びに遊離ポリゾームがい ずれるフポフェリチンの合成に関与するという結果を得 ているので上記の見解はかなり確実性を有すると考えら れる.

フェリチンの phagosomeないし phagolysosome 内 集積の所見が本実験群に見出される点化就ては内生性 のフェリチンの増量によるというよりは細胞外よりの Kupffer 細胞内へのフェリチンの多量の移入によると考 えられるのであって，その機構は正確なことは判らなく とも以前より Kinney ら40)ついで Kent ら ${ }^{38)}$ つっ て障害肝組織の鉄に対する親和性の克進に基つくとされ た.

Klavins ら 42) はエチオニン投与䀒の超微形態所見と してフェリチン蓄積の初期像として大型PAS反応陽性の pericanalicular body の出現を記載し,このものは血 鉄素の出現に先立ってフェリチンを䝪えており（二次ラ イソゾームに相当), そののちに Perls 鉄反応陽性の細 胞構造物として認められるようになると述べ，この現象 を肝組織の鉄に対する親和性に関連させているが，氏ら がフェリチン自身の産生部位は遊離リボゾームとみなし たとと ${ }^{41)}$ は既述した. Hicksら30) むとの見解を支持す る成績を得ていることをつけ加えておく.

扨，フェリチンが細胞外より細胞質内に望らされる場 合, フェリチン粒子の細胞膜通過の機構が問題となる が，このことに関しては生化学の見地からは酸化還元の 反応の関与55)が考光られる一方，フェリチンの細胞膜 通過には貫喰の機転を重視する必要があり，その意味 で phagosome や lysosome の役割が注目されてい $3^{81)}$.

さらに同じ phagolysosome 内にセロイド色素顆粒と フェリチン粒子ないしへモジデリン顆粒が共存する所見 について論ずる場合, セロイド色素顆粒に関しては，数 少ない rOB や OG を含有する小さな phagolysosome 
からライソゾーム相互の融合・発育とともに多くの rOB および OG 相互の融合・発育, しかもライソゾーム内水 解酵素による消化・処理を受けつつ形成されて行くとみ なされる.一方フェリチン粒子ないしへモジデリン顆粒 に関しては, phagolysosome 内で形成されて増量を続 け，幾つかのセロイド色素顆粒（またはセロイド色素の 前駆物質の小集落）の間や phagolysosome 辺 縁 部の 狭い基質を埋めるように多量のフェリチン様粒子が分布 し (Fig.11-a.), さらに phagolysosome より恰かも 発芽するかのように 細胞質基質内へ排出され（Fig.11b.), 遂に siderosome が形成される。 また $\mathrm{CCl}_{4}$ ガス 吸入により生じた出血およびその後惹き起こされた類洞 内血液停滞現像 28) の結 果, 肝星細胞内に貪喰された赤 血球（ないしへモグロビン）がライソゾーム内で消化・ 処理される過程においてフェリチン粒子が出現したもの と思われる一方, 細胞質基質内に量は多くはないが，実 験初期より洒漫性分布し, siderosome の形を全く示さ ない場合もみられるので, フェリチン粒子のラインゾー ム内の超微形態的に限定された有形成分のみの所見によ るフェリチン粒子のライソゾーム生成説に関してはこれ を支持し難い所見もみられると言えよう。

siderosome の本態汇関する一つの見方としてミトコ ンドリフ由来説(1) 62） 80)があるが，一応注意される. この種の見解の内で， Richter ${ }^{62)}$ はミトコンドリフに 由来するとみなされる構造物中に一モジデリン顆粒を認 めたと述べ, Theron 580) は鉄過利食慨飼育ラット肝 の変性ミトコンドリア内にフェリチン粒子が蓄積され， ミトコンドリフの变性が進むにつれて增量し, 遂に siderosome を形成するに至ってこの siderosome から フェリチンが細胞の基質内に放出されて肝の siderosis が完成されてゆくとみなしている．Bessis ら3）は低色 素性過鉄血症性賀血 (hypochromic hypersideremic anemia）例に就て 網状赤血球の 変性ミトコンドリアの crista に接して多量のフェリチンないし含鉄ミセルが 沈着する所見を示している．しかも氏ら 2 は骨髄に於 て 細網細胞の放出するフェリチン粒子は有核赤血球へ pinocytosis の現象を通して俢透することによってその 細胞質内に分布するに至り，とくにミトコンドリア内， とくに crista 相当部位偣蓄積している所見を示してい る.しかし上記の所見はかなり限定された特殊な条件下 でみられるのではないかという見方も成立する。という のは Wessel ら85)の示したコロイド鉄ないしへモグロ ビン鉄に対する大喰細胞の貪喰所見によるとこれらの鉄 ミセルは 細胞膜の陥凹に由来する構造物内に 蓄積して siderosome を形成するが，その際この siderosome の
付近のいくつかのミトコンドリア内には鉄ミセルは全く 認められず, しかもこの場合, 互いに近接する siderosome とミトコンドリフとの間に移行ないし 相似を思わ せる所見もみとめられないからである。

上記 Wessel ら ${ }^{85)}$ の記載した鉄を捕捉している構造 物は田中78）のいわゆる segresome にほほ相当してい るものとみられ, Gordon (520) や De Duve ら8) の phagosome ないし phagolysosome 飞該当していると むみられ，いゔれにせよ細胞膜由来が考えられるのみな らず，田中の見解78) からみると segresome（田中）は 氏の実験成績にみられるようにカルミン，トリパンブル 一, 中性赤のような生体染色色素顆粒が細胞外より細胞 内に浸透しようとする場合に形成されて pinocytosis の現象を生ずるとされているので siderosome がこの ような機転で形成されるとすると，この際のフェリチン 粒子の起源は細胞外に求められるべきである。しかし， フェリチン粒子の由来が erythrophagocytosis に求め られる場合に就ては，七ロイド色素フフェリチン粒子な いしへモジデリンの両色素が同一の素材から生成される 可能性を考えることが出来る。

Hampton ${ }^{24)}$ 嫁家新生仔䀒細胞内に広く分布してい るフェリチン粒子は erythrophagocytosis 化由来する とみなし，その根拠となる電顕所見として䀒細胞質（氏 は家兔新生仔肝に於ては肝細胞と Kurffer 細胞との両 者の区別は困難であるとして，この両者を肝細胞で代表 させるような取扱いをしている）内大型空胞で中心部に 高電子密度小体を容れ，その周辺加空胞辺縁に至る網 状構造を有するものは高電子密度小体を容れている変性 赤血球にほかならないとし，その周辺の網状構造の索よ り空胞辺縁部に於てはフェリチン粒子が濃密汇認められ るが，これらの粒子は中央部の変性赤血球の一モグロビ ン鉄に由来すると述べ，上述の erythrophagocy tosis の所見は新生仔に限ってみられる特異な現象とみなし ている．成熟動物肝でもその頻度は遥かに少ないとは言 え, erythrophagocytosis の現象が起こっていること が推定できる点で Hampton の 報告は示唆する点が多 いと言える。

他方，本実験成績の示す Kupffer 細胞質基質内フ リチン粒子は erythrophagocytosis に伴って大部分が 形成されたと思われるが，異常な刺激状態にある Kupffer 細胞膜（その透過性の異常な六進が考えられる）を 通して血中より䙹らされた可能性も考元られる.

また，セロイド色素と血鉄素との共存所見に関して erythrophagocy tosisの結果であるとすれば（既述)， 両色素は共通の素材から生成されたことになるが，そう 
でない場合，例えば $\mathrm{CCl}_{4}$ ガス吸入により惹き起こされ る䀒小葉中心帯の出血壊死の結果, 壊死肝細胞の星細胞 による領喰が色 素の由来とされるような場 合（当教室 で検討中）は phagolysosome 内で両色素の共存がみと められてる異なる素材から生成されると言うことも出来 る.このことより，両色素の共存所見から直ちに両色素 が共通の素材から由来すると考えるには，なお慎重な検 討を要すると思われる.

しかし， $\mathrm{CCl}_{4}$ 中毒マウス肝において小葉中心帯の出 血および血液停膟にもとずく赤血球貪喰現象を光顕およ び電顕的にしばしば見出した本実験成績を考㦄すると本 実験で示したセロイド色素と血鉄素の共存所見は両色素 が赤血球（ないしへモグロビン）という共通素材から生 成された可能性を強く示唆していると言える。

\section{V. 結埨}

マウスに対する $\mathrm{CCl}_{4}$ ガス吸入実験によるKupfer 細 胞内セロイド色素の生成過程を長期に亘って超微形態的 に観察したが, Kupffer 細胞に於て赤血球貪喰現像がし ばしば見出されるのみならず，フェリチン様粒子ないし へモジデリン顆粒がセロイド色素顆粒含有 phagolysosome 内にその量の多少に拘らずに出現することを見出 した.このことは, 赤血球が phagolysosome 内に共存

文

1) Adachi, H. : Pathological study on experimental Heinz Body anemia : Intracellular changes of phagocytized red cell in macrophages of the spleen and liver. Acta Path. Jap., 27, 657, 1977.

2) Bessis, M. and Brenton-Gorius, J. : Iron particles in normal erythroblasts and normal and pathological erythrocytes. J. Biophys. Biophem. Cytol., 3, 503, 1957.

3) Bessis, M. and Brenton-Gorius, J. : Ferritin and ferruginous miscells in normal erythroblasts and hypochromic hypersideremic anemias. Blood, 14, 423, 1959.

4) Bessis, M. and Brenton-Gorius, J.: Différents aspects du fer dans l'organisme. II. Différents formes de 1'hémosidérine. J. Biophys. Biochem. Cytol., 6, 237, 1959. 5) Bradford, W.D., Elchlepp, J.G., Arstila,
するセロイド色素とフェリチン様粒子ないしへモジデリ ン顆粒の共通の起源となり得るという見解を支持するす のである.この際, 超微形態観察に応用したへモジデリ ン除去法を用いることによって上記フェリチン粒子ない しへモジデリン顆粒の存在を組織化学的に確認した。 た $\mathrm{CCl}_{4}$ ガス長期吸入実験の終末像で 実験終了後の放置 期間のある例む含めて Kupffer 細胞内における 極めて 多量の成熟セロイド色素の存在が見出される一方, 短期 実験では常にセロイド色素顆粒と共存していたフェリ チン粒子ないしへモジデリン顆粒がセロイド色素含有 phagolysosome からこの場合ほとんど消失していた. この所見はセロイド色素顆粒の強い細胸内䕬積傾向に反 してへモジデリン顆粒は色素完成後も lysosome を通 じてフェリチン粒子の形で絶えず細胞外に排出され続け ることを示唆するあのである.

本論文の要旨は，第65回日本病理学会紛会において発 表した.

稿を終るに当り，終始ここ愁篤なる御指導，御校閲を 賜った恩師前田隆英教授に深甚の 謝意を表しますと共 に; 本実験において様々な御協力をいただきました第一 病理学教室の教室員各位に心から御礼申し上げます。

A. D., Trump, B.F. and Kinney, T. D. : Iron metabolism and cell membrane. I. Relation between ferritin and hemosiderin in bile and billiary excretion of lysosome contents. Am. J. Path., 56, 201, 1969.

6) Casselman, W.G. : The in vitro preparation and histochemical properties of substances resembling ceroid. J. Exp. Med., 94, 549, 1951.

7) Collet, A. J. and Petrik, P. : Electron microscopic study of the in vivo erythrophagocytosis by alveolar macrophages of the cat. I. Early periode : Hemolysis. Z. Zellforsch., 116, 464, 1971.

8) De Duve, C. and Wattiaux, R. : Function of lysosome. Ann. Rev. Physiol., 28, 435, 1966.

9) Dubin, I.N. : Idiopathic hemochromatosis and transfusion siderosis. A review. Am. 
J. Clin. Path., 25, 514, 1955.

10) Edwards, J.E. and Dalton, A.G. : Induction of cirrhosis of the liver and of hepatomas in mice with carbon tetrachloride. J. Nat. Canc. Inst., 3, 19, 1942.

11) Edwards, V.D. and Simon, G.T. : Ultrastructural aspects of red cell destruction in normal rat spleen. J. Ultrastr. Res., 33, 187, 1970.

12) Essner, E. : An electron microscopic study of erythrophagocytosis. J. Biophys. Biochem. Cytol., 7, 329, 1960.

13) Farrant, J. L. : An electron microscopic study of ferritin. Biochim. Biophys. Acta, 13. 569, 1954.

14) Fedorko, M.E., Cross, N.L. and Hirsch, J. G. : Appearance and distribution of ferritin in mouse peritoneal macrophages in vitro after uptake of heterologous erythrocytes. J. Cell Biol., 57, 289, 1973.

15) Finch, S.C. and Finch, C.A. : Idiopathic hemochromatosis; An iron storage disease. Medicine, 34, 3811955.

16) Gillman, J. and Gillman, T. : The pathogenesis of cytosiderosis(hemochromatosis) as evidenced in malnourished Africans. Gastroenterol., 8, 19, 1947.

17) Gillman, T., Hathorm, M. and Canham, P.A.S. : Experimental. dietary siderosis. Am. J. Path., 35, 349, 1959.

18) Golberg, L. and Smith, J. P. : Changes associated with the accumulation of excessive amounts of. iron in certain organs of the rat. Brit. J. Exp. Path., 39, 59, 1958.

19) Golberg, M.A., Chir, M.B., Phil, D. Sc. D. and Smith, J.P. : Iron overloading and hepatic vulnerability. Am. J. Path., 36, 125, 1960.

20) Gordon, G. B., Miller, L.R. and Bensch, K.G. : Studies on the intracellular digestive process in mammalian tissue culture cells. J. Cell Biol., 25, 41, 1965.

21) Gössner, W. : Histochemischer Nachweis der organischen Trägersubstanz im Hämo- siderinpigment. Virchows Arch., 323, 685, 1953.

22) Grieson, I. and Lee, W.R. : Erythrocyte phagocytosis in the human trabecular meshwork. Brit. J. Ophthal., 57, 400, 1973.

23) Hamperl, H. : Über fluorescierende Körnchenzellen („Fluorocyten“). Virchows Arch., 318, 32, 1950.

24) Hampton, J.C. : An electron microscopic study of the source and distribution of ferritin in hepatic parenchymal cells of the newborn rabbit.. Blood, 15, 480, 1960.

25) Harris, I.M., McAluster, J. and Prankerd, T.A.J. : Splenomegaly and the circulating red cell. Brit. J. Haemat., 4, 97, 1958.

26) Hartroft, W.S. : In vitro and vivo production of a ceroid-like substance from erythrocytes and certain lipids. Science, 113, 673, 1951.

27) Hartroft, W.S. and Ridout, W.S. : Pathogenesis of the cirrhosis produced by choline deficiency. Am. J. Path., 27, 951, 1951.

28) Hase, T. : Hepatic microcirculatory changes in acute and chronic carbon tetrachloride poisoning in rats. Am. J. Path. 49B, 1069, 1966.

29) Herbut, P.A. and Tamaki, H.J. : Cirrhosis of the liver and diabetes, as related to hemochromatosis. Am. J. Clin. Path., 16. 640, 1946.

30) Hicks, S.J., Drysdale, J.W. and Munro, H.N. : Preferential synthesis of ferritin and albumin by different populations of liver polysomes. Science, 164, 584, 1969.

31) Huecks, W. : Pigmentstudien. Zieglers Beitr., 54, 68, 1912.

32）伊原信夫，萩原辰治，金沢浩吉，中野患明，近藤 直, 大和利子：Hemoch romatosis $の 1$ 部検例 について 一とくに鉄反応陰性色素（いわゆる Hemofuscin）に関する考察—最新医学, 25, 2576, 1960.

33）今井 大: 肝類洞壁構成細胞の細胞学的研究. 日 網会誌, 7, 79, 1967. 
34) Inoue, T. : Hemochromatosis; A report of three autopsy cases. Acta Path. Jap., 7 (Suppl.), 677, 1957.

35) Jandyl, J.H., Richardson-Jones, A. and Castle, W.B. : The destruction of red cells by antibodies in man. I. Observations on the sequestration and lysis of red cells alterd by immune mechanism. J. Clin. Invest., 36, 1428, 1957.

36) Jandyl, J.H., Inman, J.K., Simmons, R. H. and Allen, D. W. : Transfer of iron from serum iron-binding protain to human reticulocytes. J. Clin. Invest., 38, 161, 1959.

37) Kent, G., Volini, F.I., Orfei, E., Minick, 0.T. and de la Huerga, J.: Effect of hepatic injuries upon iron storage in the liver. Lab. Invest., 12, 1094, 1963.

38) Kent, G., Minick, O.T., Volini, F.I., Orfei, E. and de la Huerga, J. : Iron storage in $\mathrm{N}-2$-Fluorenylacetamide-induced hepatic injury. Lab. Invest., 12, 1102, 1963.

39) Kerr, D.N.S. and Muir, A.R. : A demonstration of the structure and disposition of ferritin in the human liver cell. J. Ultrastr. Res., 3, 313, 1960.

40) Kinney, T. D., Hegested, D.M. and Finch, C. A. : The influence of diet on iron absorption. I. The pathology of iron excess. J. Exp. Med. 90, 137, 1949.

41) Klavins, J. V. : Regulation of ferritin synthesis. Am. J. Path., 55, 64a, 1961.

42) Klavins, J.V., Kaufman, N. and Kinney, T.D. : Increased hepatic affinity for iron during ethionine administration. Fed. Proc., 21 (No. 2), 306, 1962.

43）近藤度一，田村 宏：食食尤る赤血球処理. Acta Haem. Jap., 30, 549, 1967.

44) Kuff, E.L. and Dalton, A.J. : Identification of molecular ferritin in homogenates and sections of rat liver. J. Ultrastr. Res., 1, 62, 1957.

45) Lee, C. : Histochemical studies of the ceroid pigment of rats and mice and its relation to necrosis. J. Nat. Cancer Inst., 11, 339, 1950.

46) Lillie, R.D., Geer, J.C. and Gútierreg, A. : The removal of histochemically demonstrable iron from tissue sections by brief exposure to sodium dithionite solution. J. Histochem. Cytochem., 11, 662, 1963.

47) Luft, J.H. : Improvements in epoxy resin embedding methods. J. Biophys. Biochem. Cytol., 9, 409, 1961.

48) MacDonald, R.A. and Mallory, K. : Hemochromatosis and hemosiderosis: Study of 211 autopsied cases. Arch. Inst. Med., 105, 686, 1960.

49) Maeda, R. : The origin and characteristics of ceroid. Acta Path. Jap., 17, 439, 1967.

50) Maeda, R., Toki, J., Tateiwa, J. and Funo, S. : A modified Lillie's dithionite reduction method of removing iron from paraffin sections applicable to the ultrastructural level. Acta Histochem. Cytochem., 11, 1978 (in print).

51) Marton, P.F. : Ultrastructural study of erythrophagocytosis in the rat bone marrow. I. Red cell engulfment by reticulum cells. Scand. J. Haemat., Suppl. 23, 1. 1975.

52) Marton, P.F. : Ultrastructural study of erythrophagocytosis in the rat bone marrow, II. Iron metabolism in reticulum cells following red cell digestion. Scand. J. Haemat., Suppl. 23, 27, 1975.

53) Matioli, G.T. and Barker, R.F. : Denaturation of ferritin and relationship with hemosiderin. J. Ultrastr. Res., 8, 477, 1963.

54) Miller, F. : Hemoglobin absorption by the cells of the proximal convoluted tubule in mouse kidney. J. Biophys. Biochem. Cytol., 8, 689, 1960.

55) Miller, J.P.G. and Perkins, D.J. : Model experiments for the study of iron transfer from transferrin to ferritin. Europ. J. Biochem., 10, 146, 1969. 
56) Miyawaki, H. : Histochemistry and electron microscopy of iron-containing granules, lysosomes, and lipofuscin in mouse mammary glands. J. Nat. Cancer Inst., 34, 601, 1965.

57) Myagkaya, G. and Vreeling-Sindelarova, H. : Erythrophagocytosis by cells of the trophoblastic epithelium in the sheep placenta in different stages of gestaion. Acta Anat., 95, 234, 1976.

58）内藤 真：Kupffer 細胞の形態と起源. 日網会 誌, 16, 25, 1976.

59) Petric, P. and Collet, A. J. : Electron microscopic study of the in vivo erythrophagocytosis by alveolar macrophages of the cat. II. Late period: Digestion. Z. Zellforsch., 116, 477, 1971.

60) Porta, E.A. : Experimental electron microscopic study of the sequential stages of in vitro formation of ceroid. Exp. Molec. Path., 2, 219, 1963.

61) Puro, D.G. and Richter, G.W. : Ferritin synthesis by free and membrane-bound (poly) ribosomes of rat liver. Proc. Soc. Exp. Biol. Med., 138, 399, 1971.

62) Richter, G.W. : A study of hemosiderosis with the aid of electron microscopy ; with observations on the relationship between hemosiderin and ferrtin. J. Exp. Med., 106, 203, 1957.

63) Richter, G.W.: Electron microscopy of hemosiderin; presence of ferritin and occurence of crystalline lattice in hemosiderin deposits. J. Biophys. Biochem. Cytol., 4, 55, 1958.

64) Richter, G.W. : The cellular transformation of injected colloidal iron complexes into ferritin in experimental animals. J. Exp. Med., 109, 197, 1959.

65) Rifkind, R. A. : Heinz body anemia : An ultrastructural study. II. Red cell sequestration and destruction. Blood, 26, 433, 1965.

66) Scheuer, P. J., Williams, R. and Muir, A.R. : Hepatic pathology in relatives of patients with hemochromatosis. J. Path. Bact., 84, 53, 1962.

67) Schmidt, F.C.: Elektronenmikroskopische Untersuchungen an den Sinusoid Wandzellen (Kupfferschen Sternzelle) der weißen Maus. Anat. Anz., 108, 376, 1960.

68) Sheldon, J.H. : Haemochromatosis. Oxford Univ. Press, London, 1935.

69) Shoden, A. and Sturgeon, P. : Hemosiderin. 1. A physicochemical study. Acta Haemat., 23, 376, 1960.

70) Simon. G. T. and Burke, J.S. : Electron microscopy of the spleen. III. Erythroleukophagocytosis. Am. J. Path., 58, 451, 1970.

71) Smith, F. : Erythrophagocytosis in human lymph-glands. J. Path. Bact., 76, 383, 1958.

72) Smith, L. and Fineberg, R. A. : Serum requirement for apoferritin induction in rat slices. Blood. 39, 274, 1972.

73) Sorenson, G. D. : Electron microscopic observation of bone marrow from patients with sideroblastic anemia. Am. J. Path., 40, 2971964.

74) Spicer, S.S. : Siderosis associated with increased lipofuscin and mast cells in aging mice. Am. J. Path., 37, 457, 1960.

75) Spicer, S.S., Simson, J.A.V. and Farrington, J.E.: Mast cell phagocytosis of red blood cells. Am. J. Path., 80, 481, 1975.

76) Stoeckenius, W. : Morphologische Beobachtung beim intracellulären Erythrocytenabbau und der Eisenspeicherung in der Milz des Kaninchens. Klin. Wschr., 35, 760, 1957.

77) Sturgeon, P. and Shoden, A. : Hemosiderin and ferritin, in "Pigment in Pathology" (ed. by Wolmann, M.). p.90, Acad. Press, New York and London. 1960.

78）田中春高：生体染色機転の電子顕微鏡的解析，特 に貪喰現象との対比に於いて。 日網会誌， 1，45, 1961.

79) Teitel, P.: Disk-sphere transformation 
and plasticity alteration of blood cells. Nature, 206, 409, 1965.

80) Theron, J.J., Hawtrey, A. O. , Liebenberg, N. and Schirren, V. : The pathogenesis of experimental dietary siderosis of the liver. Am. J. Path., 43, 73, 1963.

81) Trump, B.F., Valigorsky, J.M., Arstila, A. U., Mergner, W.J. and Kinney, T.D. : The relationship of intracellular pathways of iron metabolism to cellular iron overload and the iron storage diseases. Am. J. Path., 72, 295, 1973.

82) Vaughau, R.B. and Boyden, S.V. : Interactions of macrophages and erythrocytes. Immunol., 7, 118, 1964.

83) Wargner, H.N., Razzak, M.A., Gaertner, R.A., Caine, W.P. and Feagin, 0.T.: Removal of erythrocytes from circulation. Arch. Int. Med., 110, 90, 1962.

84) Wakefield, J. and Hicks, R.M. : Eryth- rophagocytosis by the epithelial cells of the bladder. J. Cell Sci. 15, 555, 1974.

85) Wessel, W. and Gedigk, P. : Die Verarbeitung und Speicherung von phagocytiertem Eisen im elektronenmikroskopischen Bild. Virchows Arch., 332, 508. 1959.

86）大和利子：セロイド色素の起源に関する組織化学 的研究. 一一赤血球基質䜿濁液注入によるセロイ ド色素生成について——関西医大誌, 24, 255, 1972.

87) Zeligs, J.D. : Ultrastructure of the degradation of erythrocytes by thyroid epithelial cells in vivo. Am. J. Path., 89, 85, 1977.

88) Zeligs, J.D. and Wollman, S.H. : Ultrastructure of erythrophagocytosis and red blood cell fission by thyroid epithelial cells in vivo. J. Ultrastr. Res., 59, 57, 1977. 


\section{Explanation of Figures}

Fig. 1. Light microscopical photograph of the liver from a mouse forced to inhale $\mathrm{CCl}_{4}$ vapor 65 times in 148 days. Hematoxylin and eosin stain.

Note several erythrocytes (pink) found in the hypertrophied Kupffer cell filled with yellow-brown ceroid granules.

This finding suggests that erythrophagocytosis is closely participated in the formation of ceroid. $\times 402$.

Fig. 2. Kupffer cell from the same liver shown in Fig. 1.

Iron reaction follwed by Sudan III stain on paraffin sections.

Note ceroid granules (orange) coexisting with hemosiderin (blue). $\times 670$.

Fig. 3. Fluorescence microscopical photograph of the same liver, shown in Fig. 1.

Unstained.

Note a brilliantly whitish-yellow autofluorescence of ceroid. $\times 268$.

Fig. 4. Kupfer cell from a mouse sacrificed 8 weeks after being forced to inhale $\mathrm{CCl}_{4}$ vapor 83 times in 257 days. Fixed in glutaraldehyde. Postfixed in osmic acid. Unstained.

Note an erythrocyte $(\rightarrow$ ) phagocytized by Kupffer cell containing innumerable ceroid granules. $\times 16,000$.

Fig. 5. Kupffer cells from a mouse forced to inhale $\mathrm{CCl}_{4}$ vapor 3 times in 5 days. Fixed in glutaraldehyde. Postfixed in osmic acid. Lead and uranyl stain.

Note a few erythrocytes $(\rightarrow)$ engulfed by Kupffer cells.
$\mathrm{N}$ : nucleus of Kupffer cell
$S:$ sinusoid
$\times 7,400$.

Fig. 6. Kupfer cell from a mouse forced to inhale $\mathrm{CCl}_{4}$ vapor 8 times in 18 days. Fixed in osmic acid. Lead and uranyl stain.

Note an erythrocyte ( ) phagocytized by Kupfer cell.

$\mathrm{N}$ : nucleus of Kupfer cell S: sinusoid G: Golgi apparatus Er:erythrocyte $\times 7,500$.

Inset: High magnification of an outlined area. Note innumerable ferritin-like particles (circles) in the stroma of the erythrocyte. $\times 92,000$.

Fig. 7. Kupfer cell from a mouse sacrificed 10 weeks after being forced to inhale $\mathrm{CCl}_{4}$ vapor 105 times in 315 days. Fixed in glutaraldehyde. Postfixed in osmic acid. Unstained.

Note two irregular-shaped erythrocytes phagocytized by Kupfer cell containing innumerable ceroid granules. The erythrocytes contain a vacuole with osmiophilic bodies $(1)$ or an aggregate of ferritin-like particles $(D) . \times 9,500$.

Inset : High magnification of an outlined area in the aggregate of ferritin-like particles. $\times 37,000$.

Fig. 8. Kupffer cell from a mouse forced to inhale $\mathrm{CCl}_{4}$ vapor 8 times in 18 days. Fixed in osmic acid. Unstained.

Note the phagolysosomes containing a few rounded osmiophilic bodies $(\rightarrow)$, osmiophilic granules and low osmiophilic amorphous materials.

Three square areas are enlarged in Fig. 9..

$\mathrm{N}$ : nucleus of Kupfer cell G: Golgi apparatus

$M:$ mitochondria $\quad P E$ : erythrocyte phgocytized by Kupfer cell $\times 13,000$. 
Fig. 9. High magnification of three outlined areas in Fig. 8.

a) Note an aggregate of ferritin-like particles lacking a limiting membrane in the cytoplasmic matrix. $\times 33,000$.

b) Note the ferritin-like particles scattered throughout the phagolysosomes. $\times 33,000$.

c) Note the rounded osmiophilic body ( $\square$ ) fusing with the phagolysosome. The other osmiophilic body ( ) is isolated in the cytoplasmic matrix. $\times 33,000$.

Fig. 10. Kupfer cell from a mouse forced to inhale $\mathrm{CCl}_{4}$ vapor 33 times in 78 days. Fixed in osmic acid. Unstained.

Note many irregular-shaped phagolysosomes containing rounded osmiophilic bodies and osmiophilic granules. These bodies tend to exist in the more inner area of the phagolysosomes. Two square areas are enlarged in Fig.11..

$\mathrm{N}$ : nucleus of Kupfer cell $\mathrm{H}$ : hepatocyte

$\mathrm{PE}$ : erythrocyte phagocytized by Kupfer cell $\times 13,000$.

Fig.11. High magnification of two outlined areas (a, b) in Fig.10.

a) In a large phagolysosome, rounded osmiophilic bodies are being fused to one another $(\rightarrow)$ and innumerable ferritin-like particles $(\omega)$ are scattered in the less osmiophilic area located among the clumps of osmiophilic materials. On the other hand, an aggregate of ferritin-like particles $(\square)$ is seen in the cytoplasmic matrix. $\times 55,000$.

b) Note an aggregate of ferritin-like particles $(\rightarrow)$ with a limiting membrane protruding from the phagolysosome. This appearance is suggestive of a budding. $\times 45,000$.

Fig.12. Another portion of the same Kupffer cell shown in Fig. 10. Fixed in osmic acid. Unstained.

Note the aggregates of ferritin-like particles with a limiting membrane. These are siderosomes $(\rightarrow) . \quad \times 140,000$.

Fig.13. Kupffer cell from a mouse forced to inhale $\mathrm{CCl}_{4}$ vapor 50 times in 114 days. Fixed in osmic acid. Lead and uranyl stain. $\times 18,000$.

The phagolysosomes have the clumps of electron-dense bodies varying in size and density. Some of these bodies $(\rightarrow)$ contain vacuoles with the electrondense peripheral rim.

$\mathrm{N}:$ nucles of Kupfer cell M:mitochondria

G: Golgi apparatus $\quad \mathrm{F}:$ collagen fiber $\quad \times 18,000$.

Fig.14. Kupfer cell from a mouse forced to inhale $\mathrm{CCl}_{4}$ vapor 60 times in 141 days. Fixed in osmic acid. Unstained.

Note the phagolysosomes containing osmiophilic bodies of various configurations. Some of the osmiophilic bodies $(\rightarrow)$ contain an electron-translucent vacuole with the high osmiophilic peripheral rim.

$\mathrm{N}$ : nucleus of Kupfer cell $\mathrm{S}:$ sinusoid $\times 15,000$.

Fig.15. Kupfer cell from a mouse forced to inhale $\mathrm{CCl}_{4}$ vapor 87 times in 203 days. Fixed in osmic acid. Unstained.

Note the phagolysosomes containing many osmiophilic materials of various configurations and a few ferritin-like particles ( ). There is an aggregate of ferritin- 
like particles $(\rightarrow)$ lacking a limiting membrane in the cytoplasmic matrix.
$\mathrm{N}$ : nucleus of Kupffer cell
$\mathrm{M}:$ mitochondria
$\times 29,000$.

Fig.16. Kupfer cell from a mouse sacrificed 5 weeks after being forced to inhale $\mathrm{CCl}_{4}$ vapor 83 times in 243 days. Fixed in glutaraldehyde. Postfixed in osmic acid. Lead and uranyl stain.

Note the Kupfer cell filled with innumerable phagolysosomes which contain the clumps of electron-dense materials of various configurations.

$\mathrm{H}:$ hepatocyte $\mathrm{F}:$ collagen fiber $\times 12,000$.

Fig.17. Another Kupffer cell of the same specimen shown in Fig.16..

Note a portion of a large phagolysosome containing low electron-dense ceroid granules $(\phi)$ of various configurations with high electron-dense peripheral rim.

$\mathrm{F}:$ collagen fiber $\quad \times 24,000$.

Fig.18. A portion of Kupfer cell from a mouse sacrificed 10 weeks after being forced to inhale $\mathrm{CCl}_{4}$ vapor 105 times in 315 days. Fixed in glutaraldehyde. Postfixed in osmic acid. Unstained.

A large number of phagolysosomes contain the clumps of osmiophilic materials of polymorphic configurations. Note the osmiophilic bodies comprising a number of vacuoles (osmiophilic multivacuolar structure) (1). A square area is enlarged in Fig. 21.. $\times 12,000$.

Fig. 19. A phagolysosome in Kupffer cell from a mouse sacrificed 4 weeks after being forced to inhale $\mathrm{CCl}_{4}$ vapor 83 times in 231 days. Fixed in glutaraldehyde. Postfixed in osmic acid. Unstained.

Note a high osmiophilic laminated body (1) showing a high osmiophilic fingerprint-like structure. $\times 100,000$.

Fig. 20. Another Kupffer cell of the same liver shown in Fig.18.. Unstained.

Note the internal configuration of phagolysosomes comprising osmiophilic multivacuolar structures $(\omega)$, rounded osmiophilic bodies, membranous structures $(\rightarrow)$ and only a few ferritin-like particles. There are dispersed ferritin-like particles and an aggregate of ferritin-like paticles $(D)$ in the cytoplasmic matrix. $\times 28,000$.

Fig. 21. High magnification of an outlined area in Fig.18..

Note a few ferritin-like particles (circle) scattered in the cytoplasmic matrix. There are hardly ferritin-like particles in the phagolysosomes.

Mn : limiting membrane $\quad$ CMX : cytoplasmic matrix $\quad \times 110,000$.

Fig. 22. Another Kupfer cell of the same liver shown in Fig.19.. Unstained.

Note ferritin-like particles (circle) existing in the restricted area of the cytoplasmic matrix among the phagolysosomes containing ceroid granules ( ).

$\mathrm{CM}:$ cell membrane $\mathrm{M}:$ mitochondria $\times 53,000$.

Fig. 23. Another portion of the same specimen shown in Fig.22..

Note an aggregate of ferritin-like particles $(\rightarrow)$ located among phagolysosomes containing ceroid granules. $\times 86,000$.

Fig. 24. Kupfer cell of the same mouse shown in Fig.22.. Fixed in glutaraldehyde. Unstained.

Note many ferritin-like particles accumulating in the peripheral area (1) of the cytoplasm and among phagolysosomes ( $\downarrow)$. On the other hand, there are only a few ferritin-like particles (circles) in phagolysosomes containing ceroid gr- 
anules $(D) . \quad \times 40,000$.

$F$ : collagen fiber

Fig. 25. Kupffer cell from a mouse sacrificed 5 weeks after being forced to inhale $\mathrm{CCl}_{4}$ vapor 83 times in 243 days. Fixed in glutaraldehyde, treated with $1 \% \mathrm{Na}_{2} \mathrm{~S}_{2} \mathrm{O}_{4}$ to remove hemosiderin and postfixed in osmic acid. Unstained.

Ferritin-like particles are visible neither in phagolysosomes nor in the cytoplasmic matrix.

$\mathrm{N}$ : nucleus of Kupfer cell $\quad \times 40,000$. 


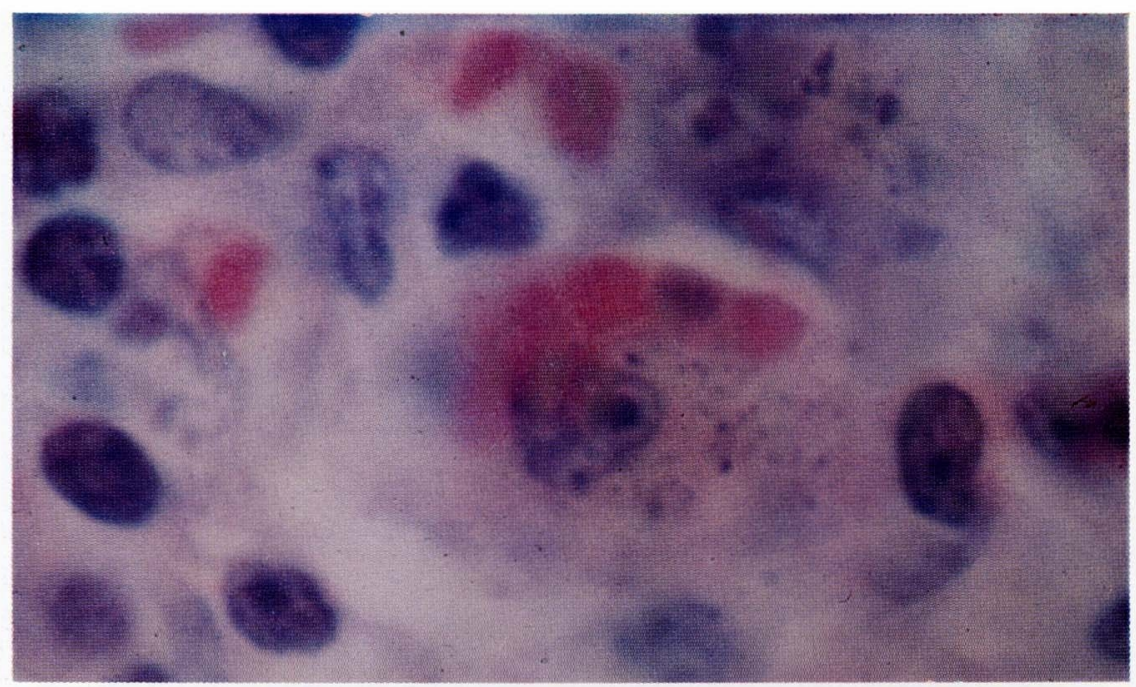

Fig. 1 .

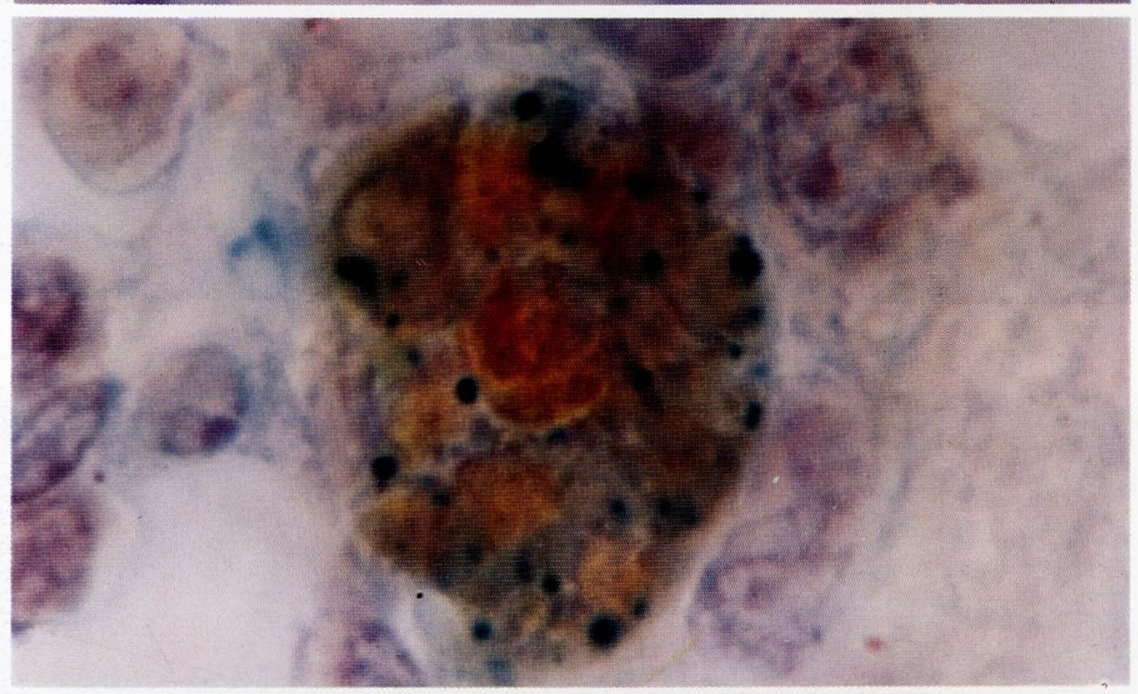

Fig. 2 .

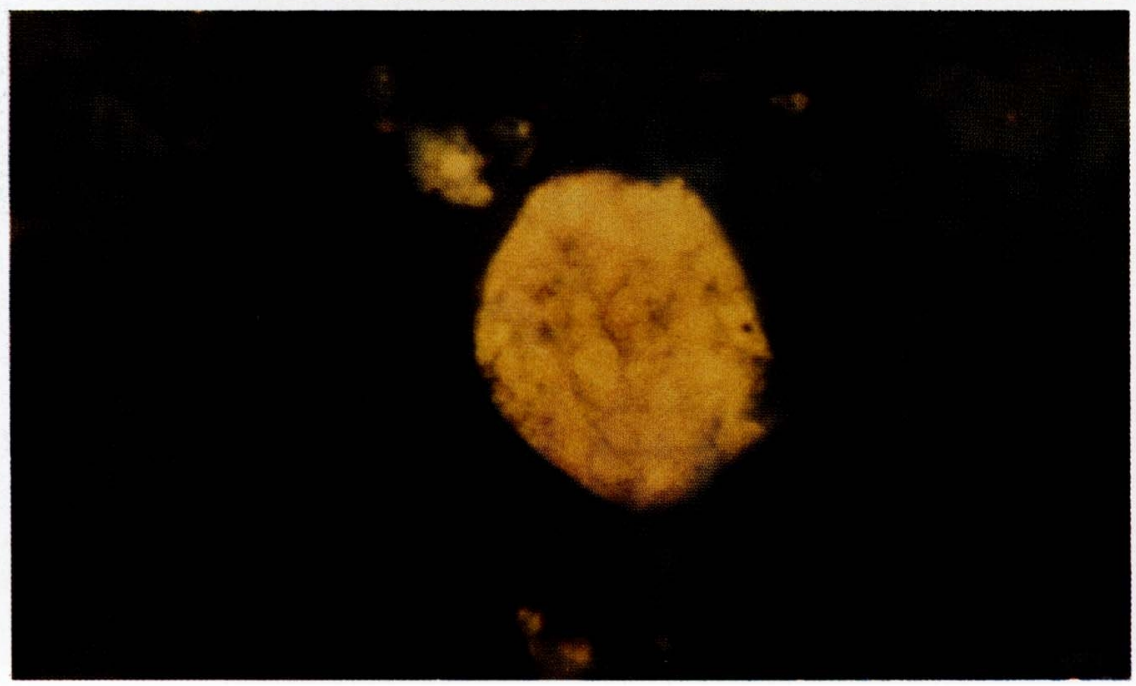

Fig. 3 . 

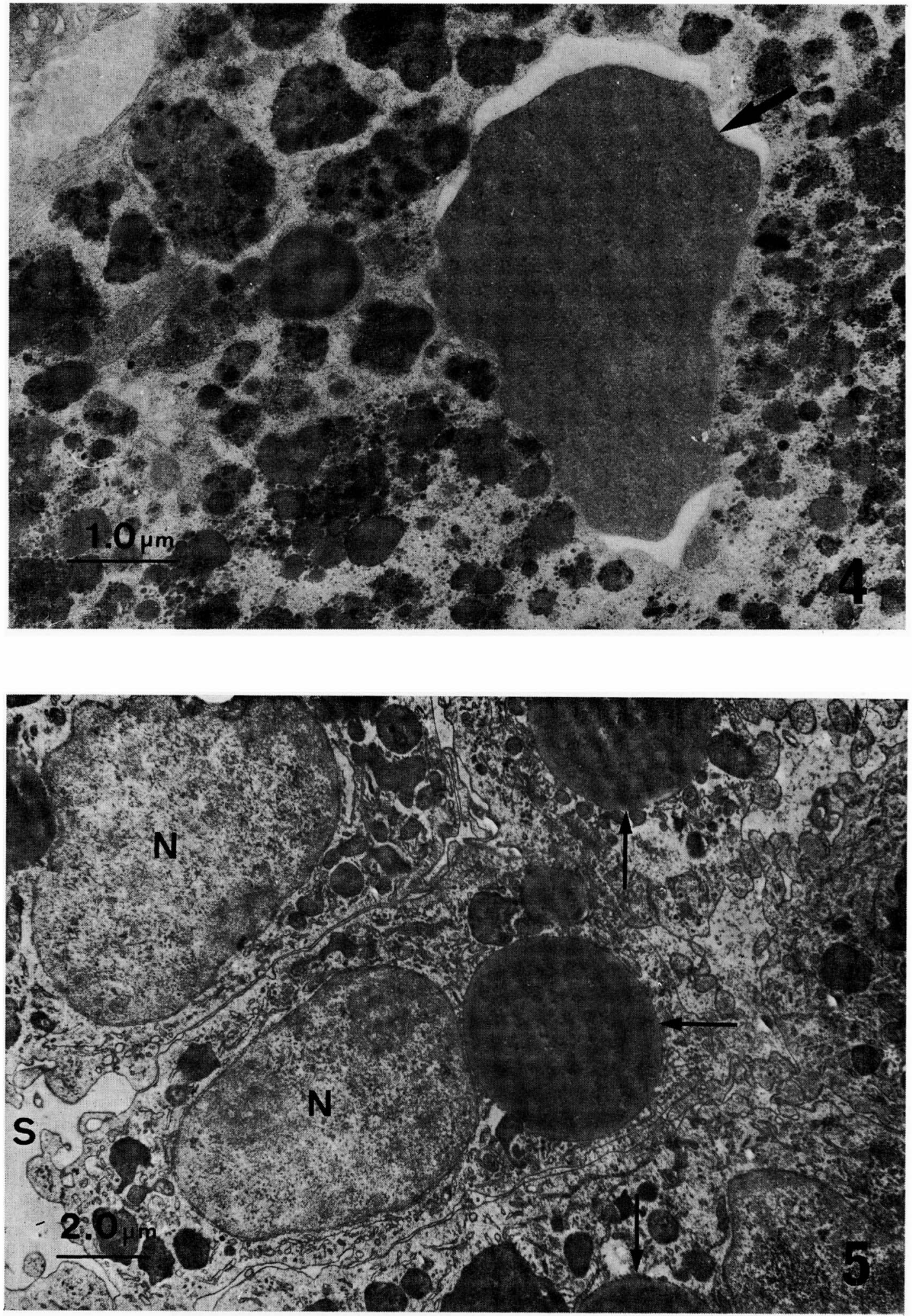

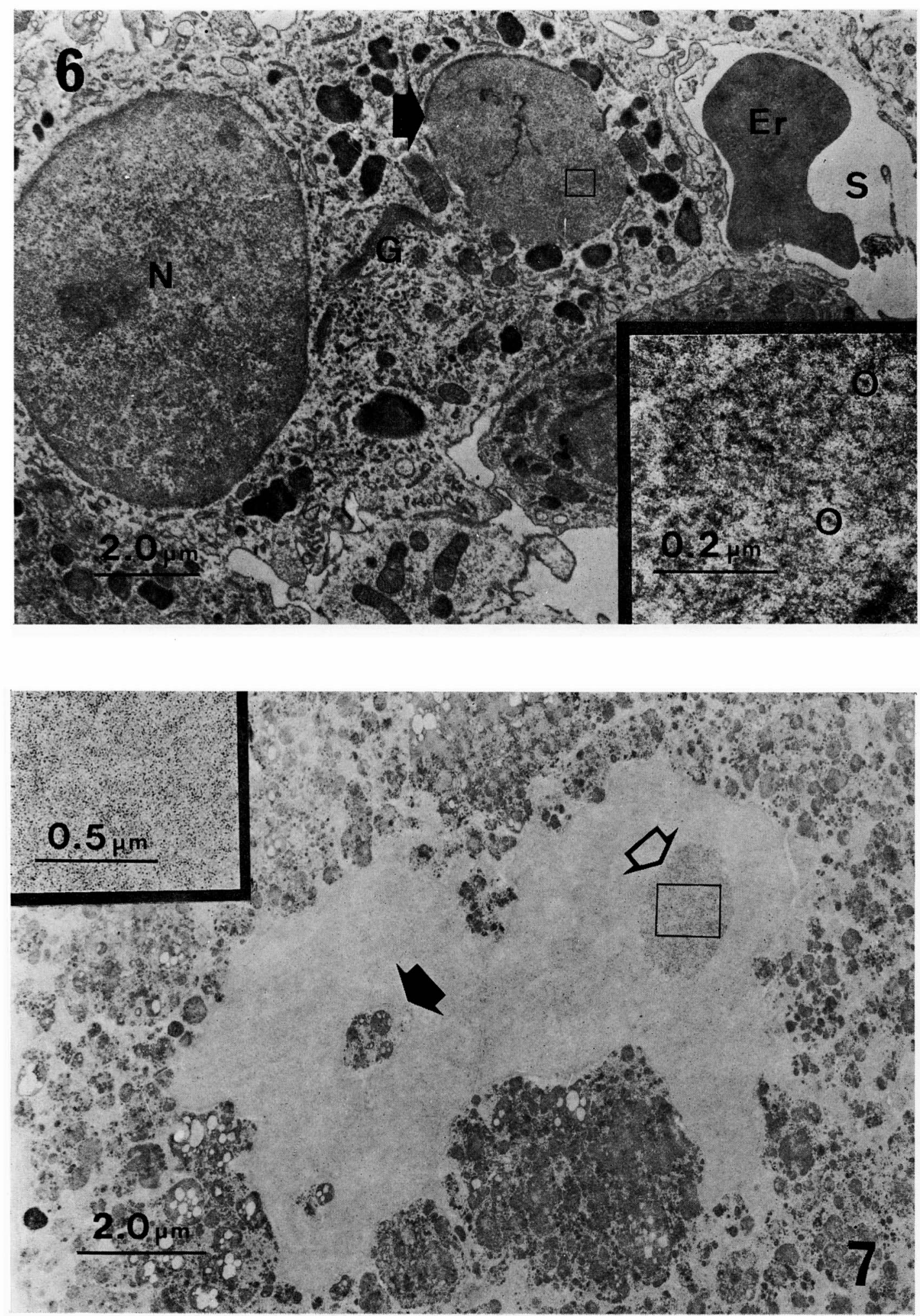

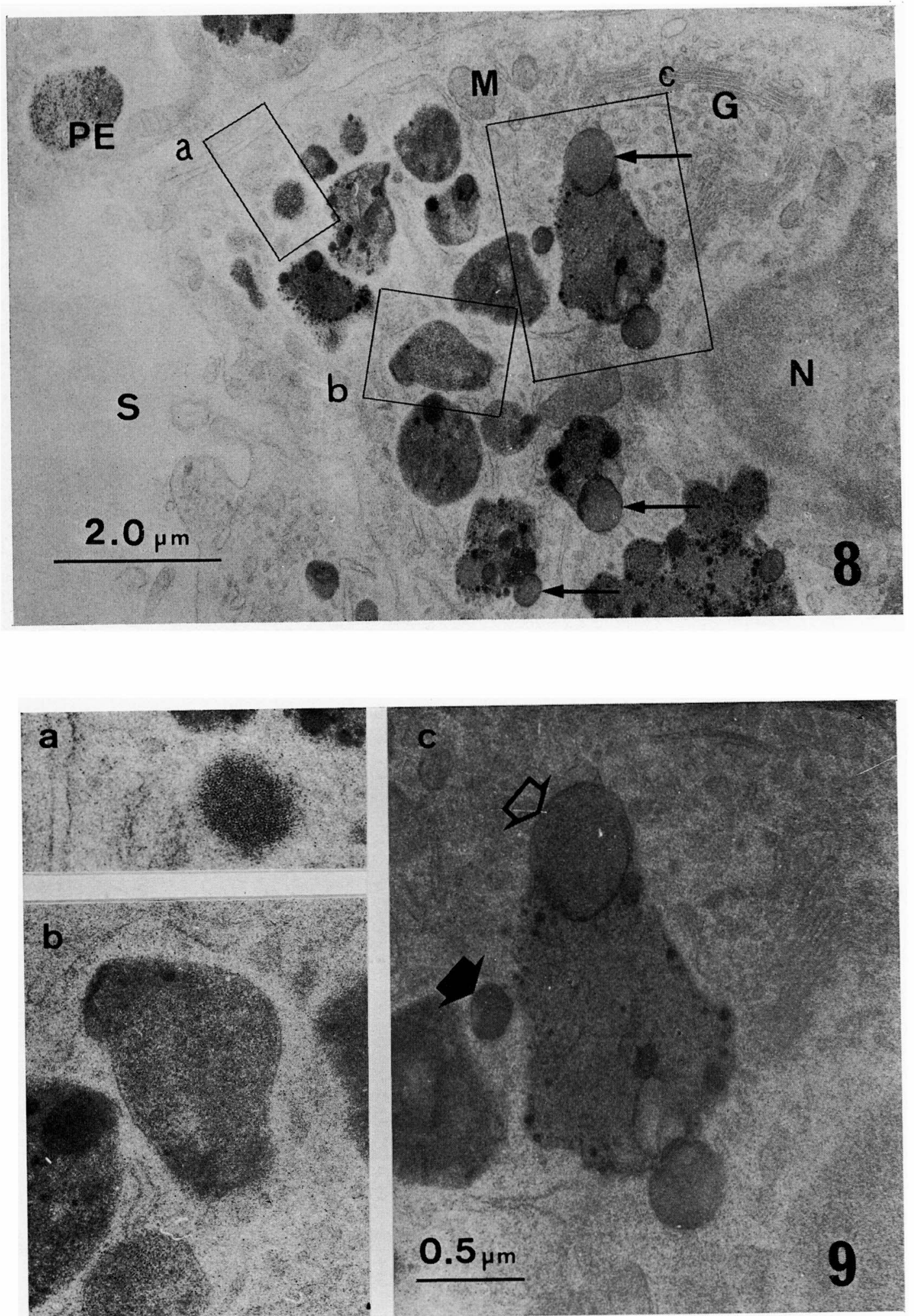


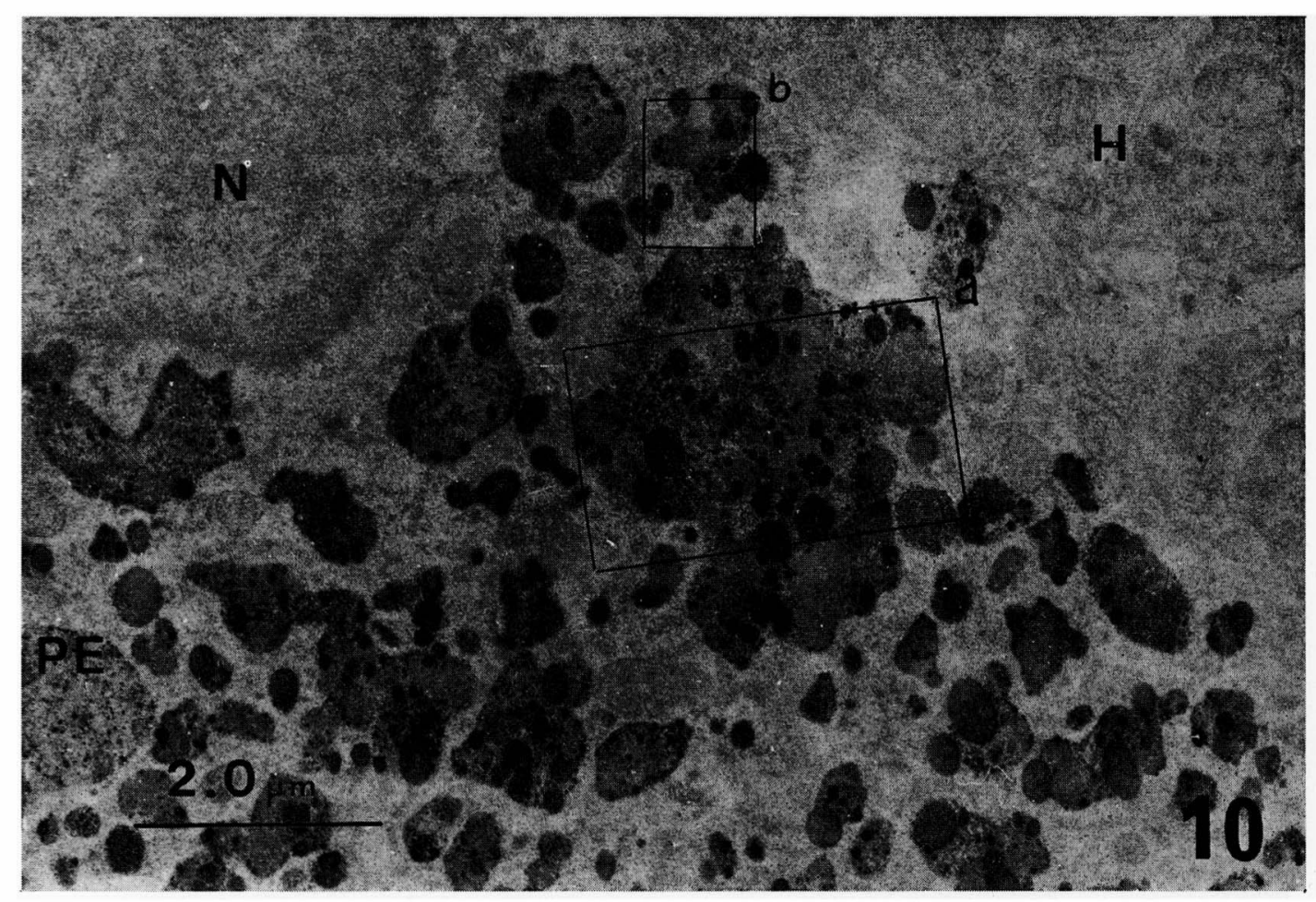



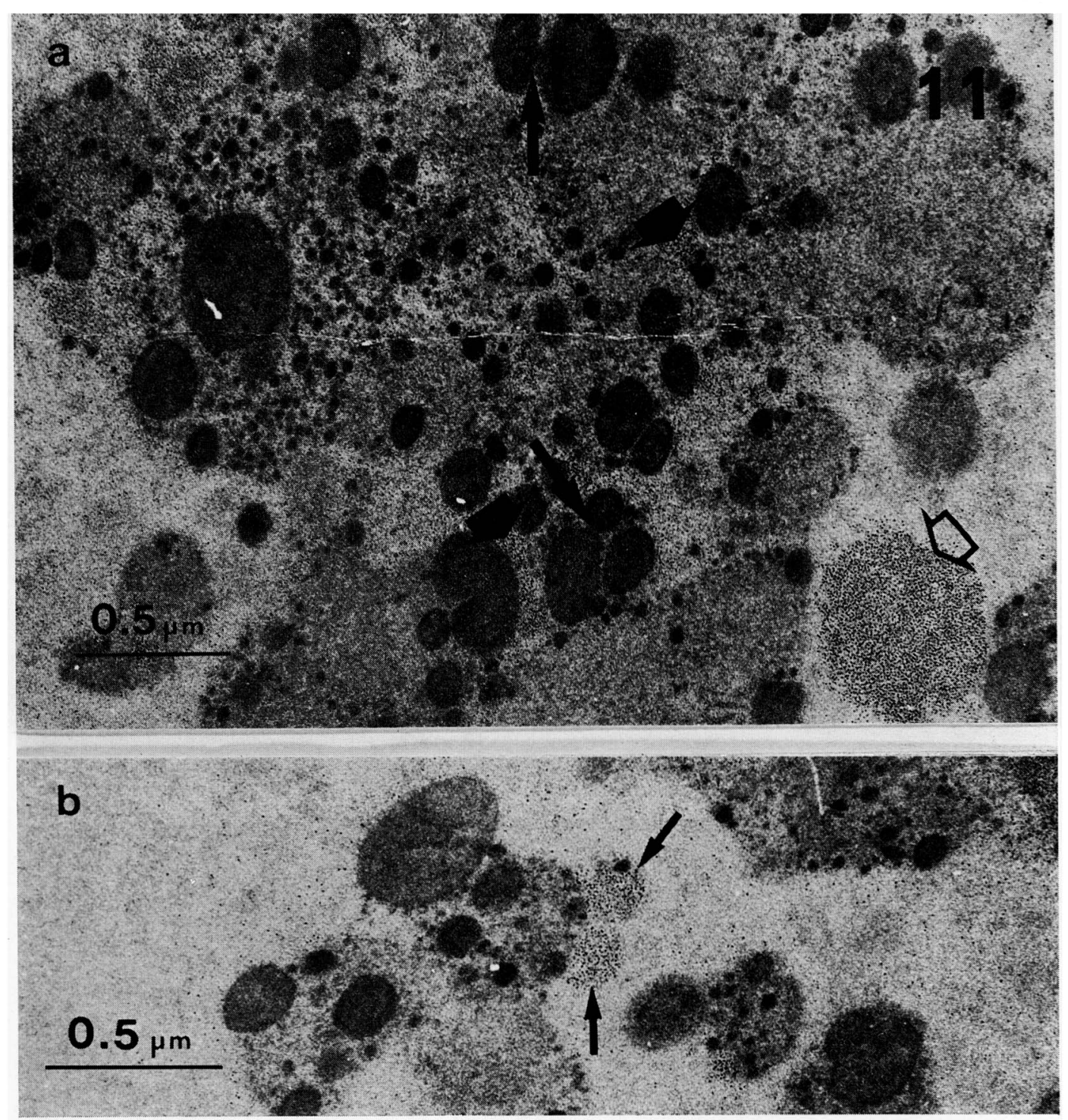

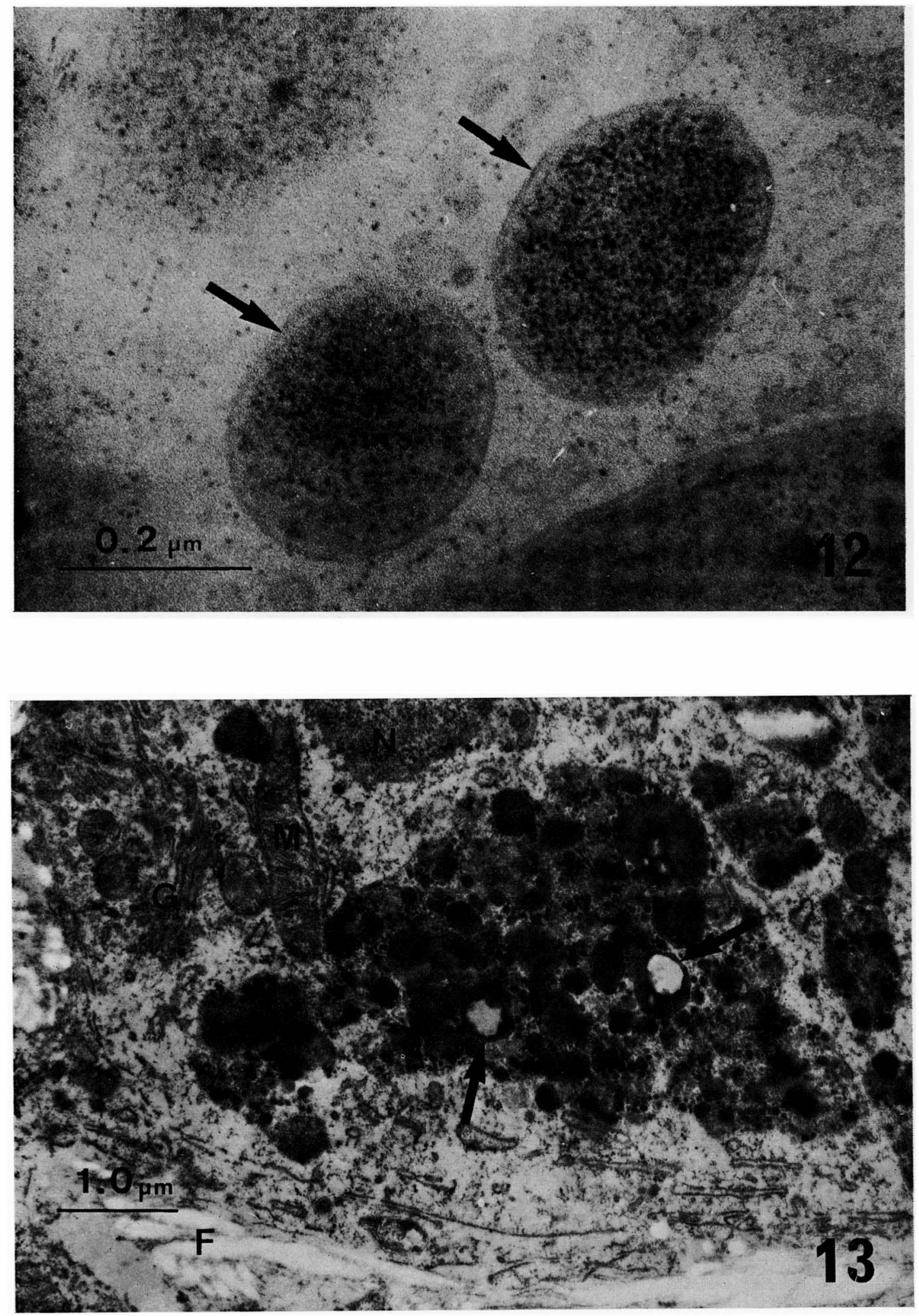

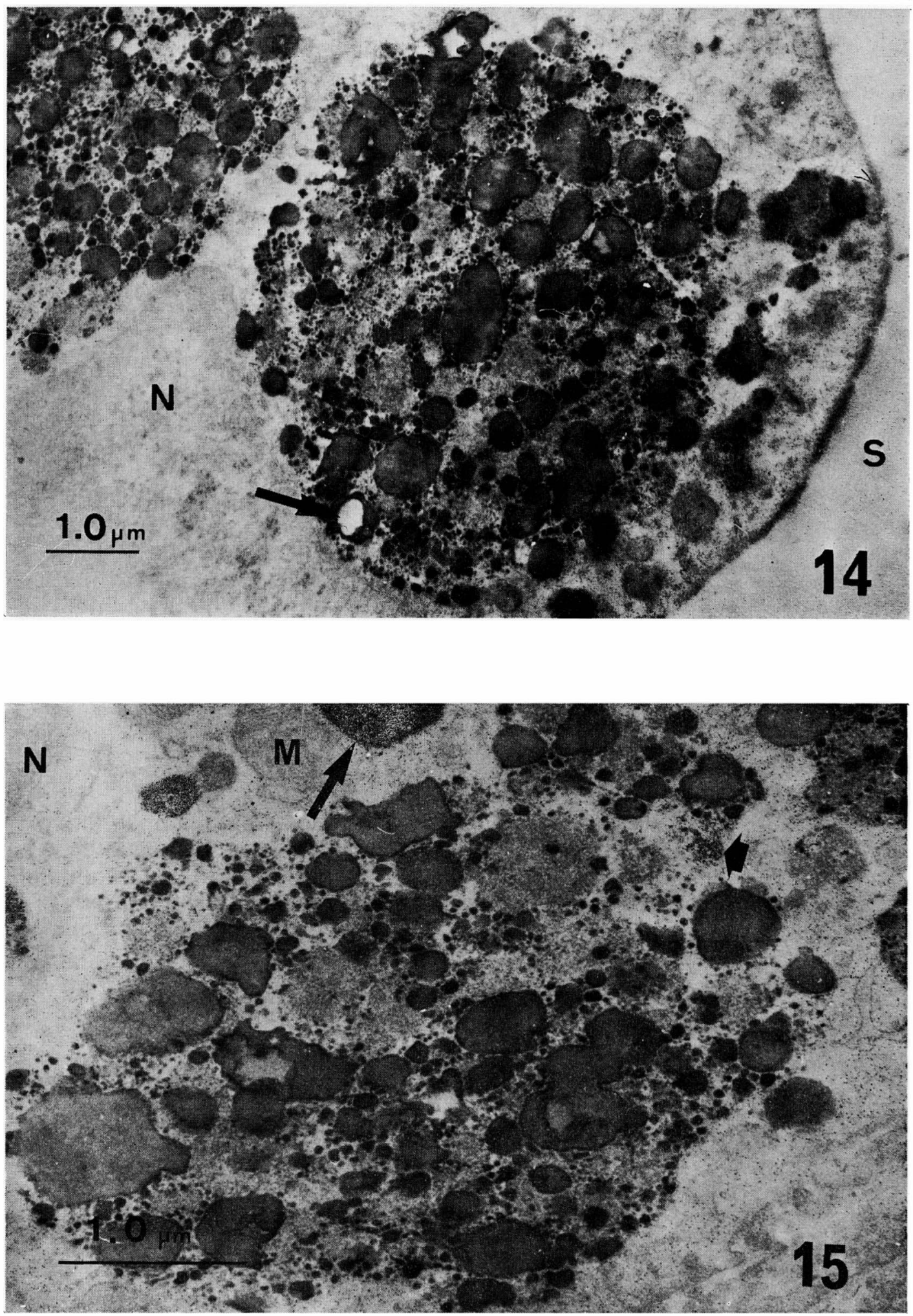

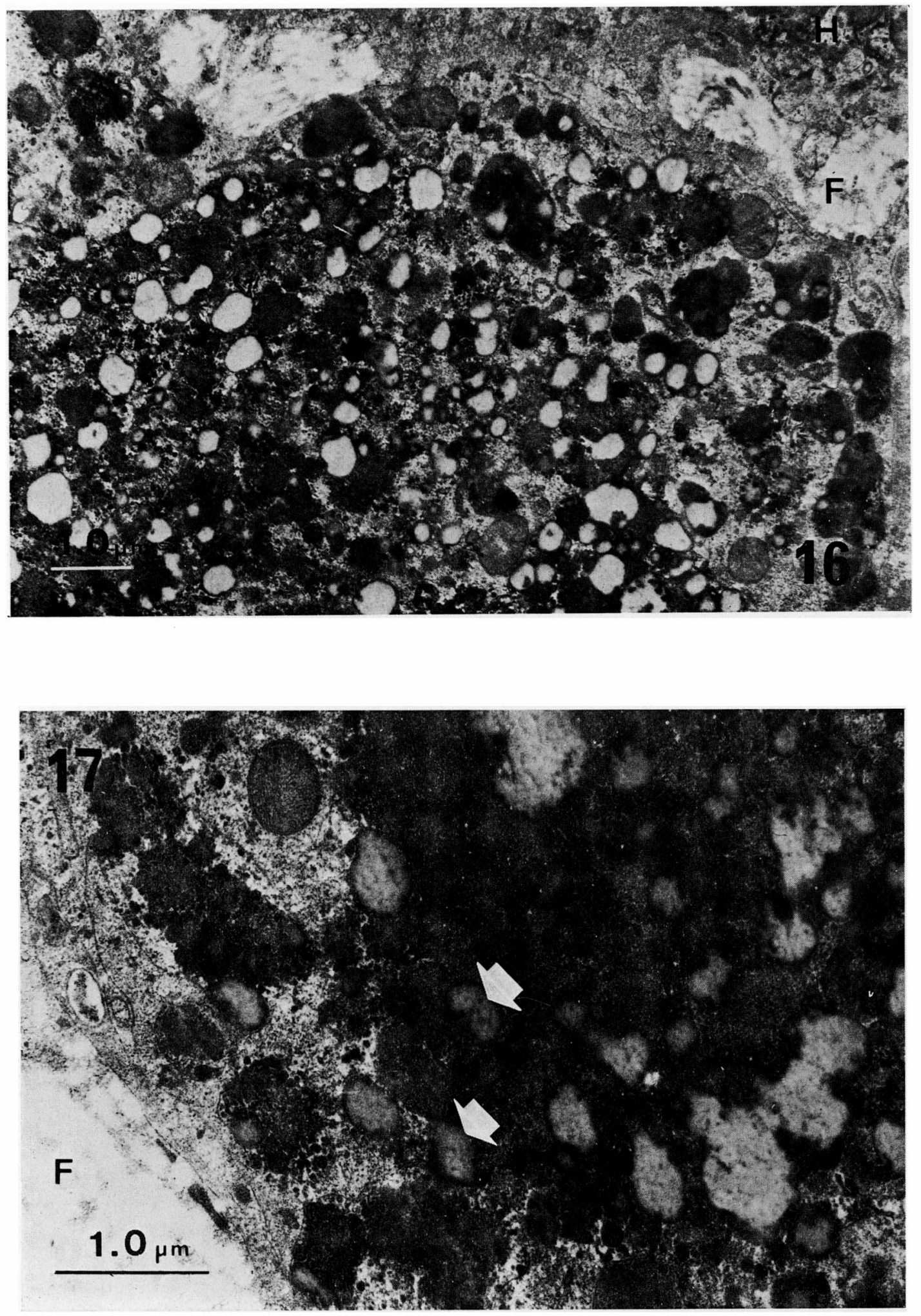

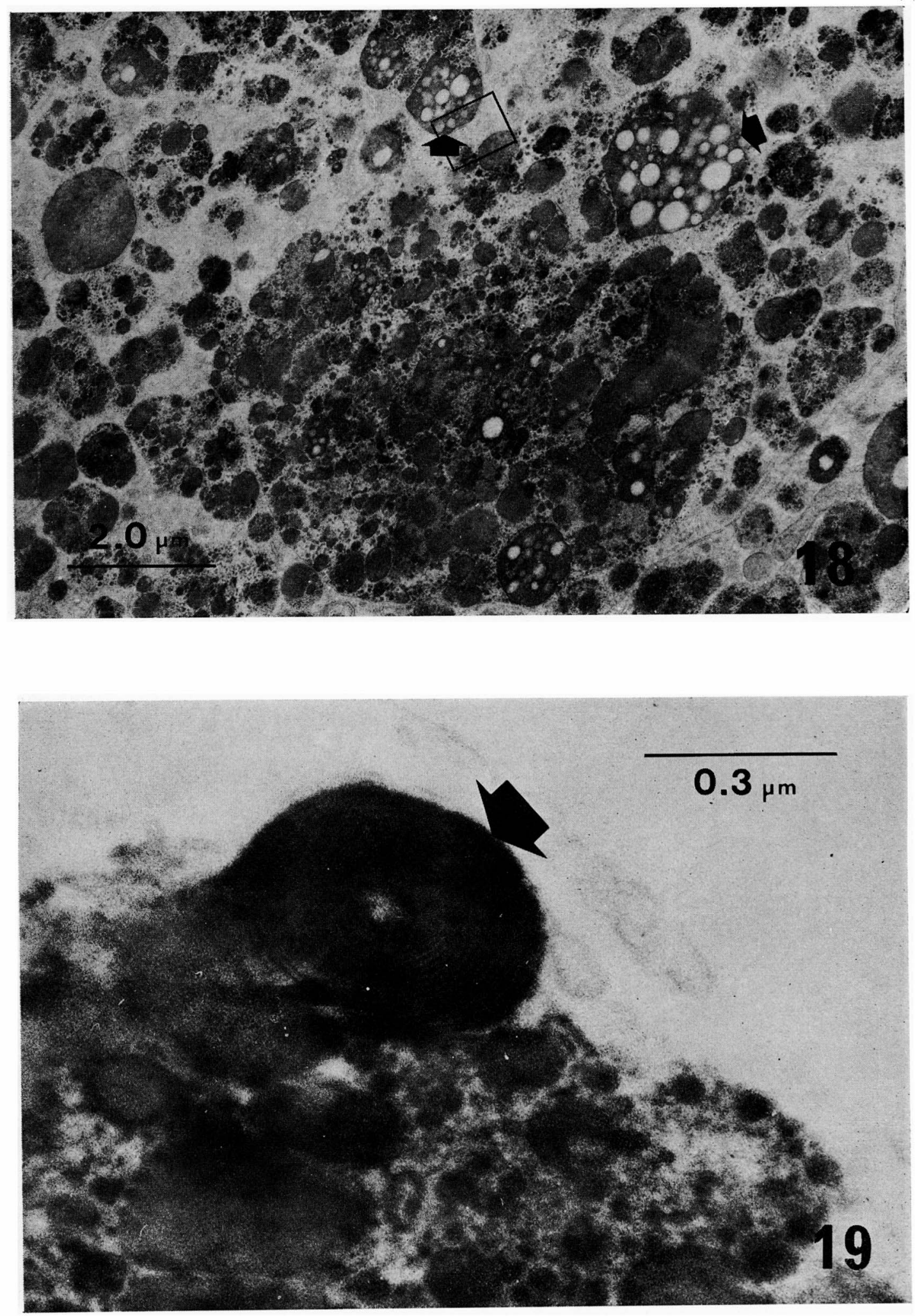

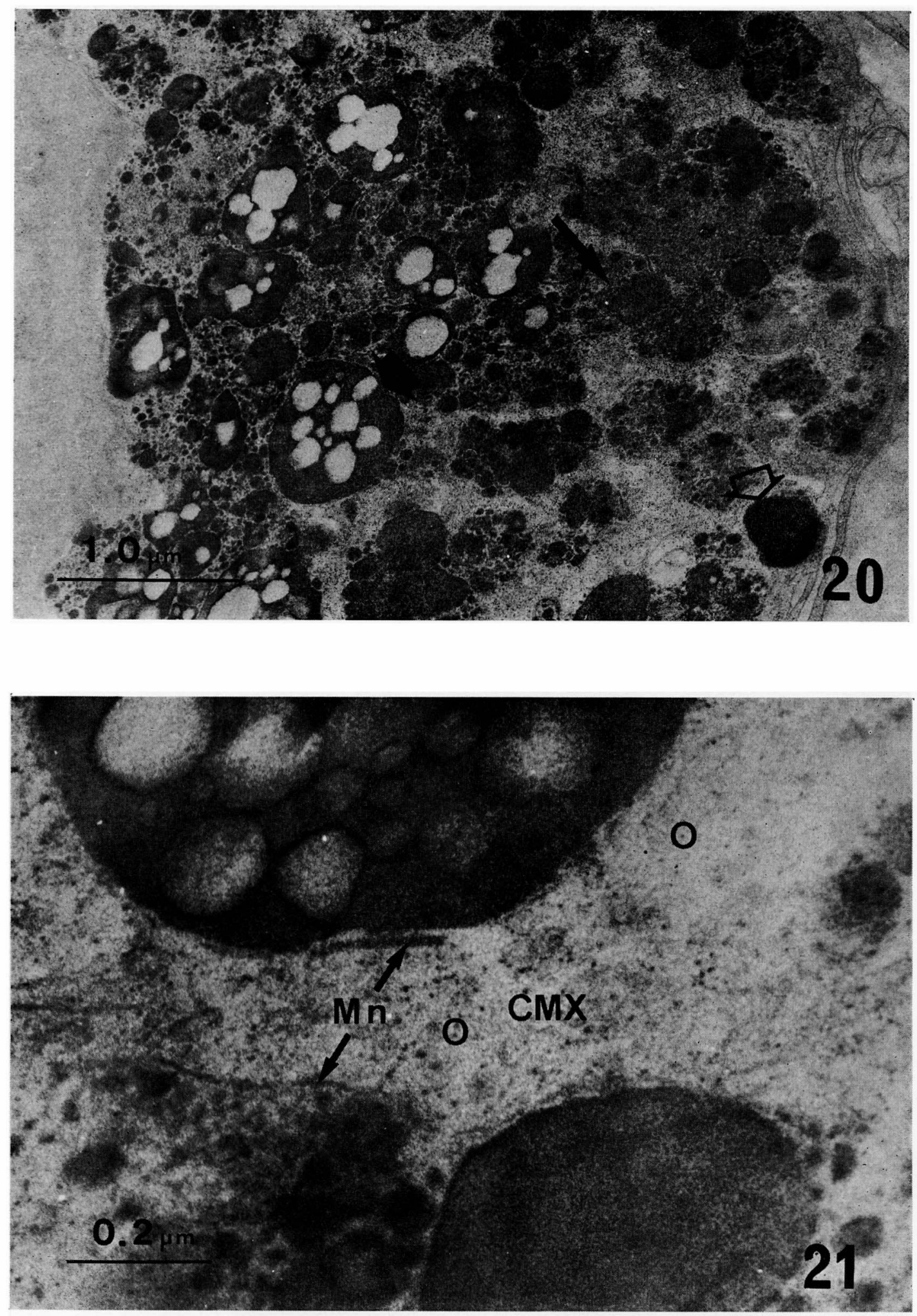

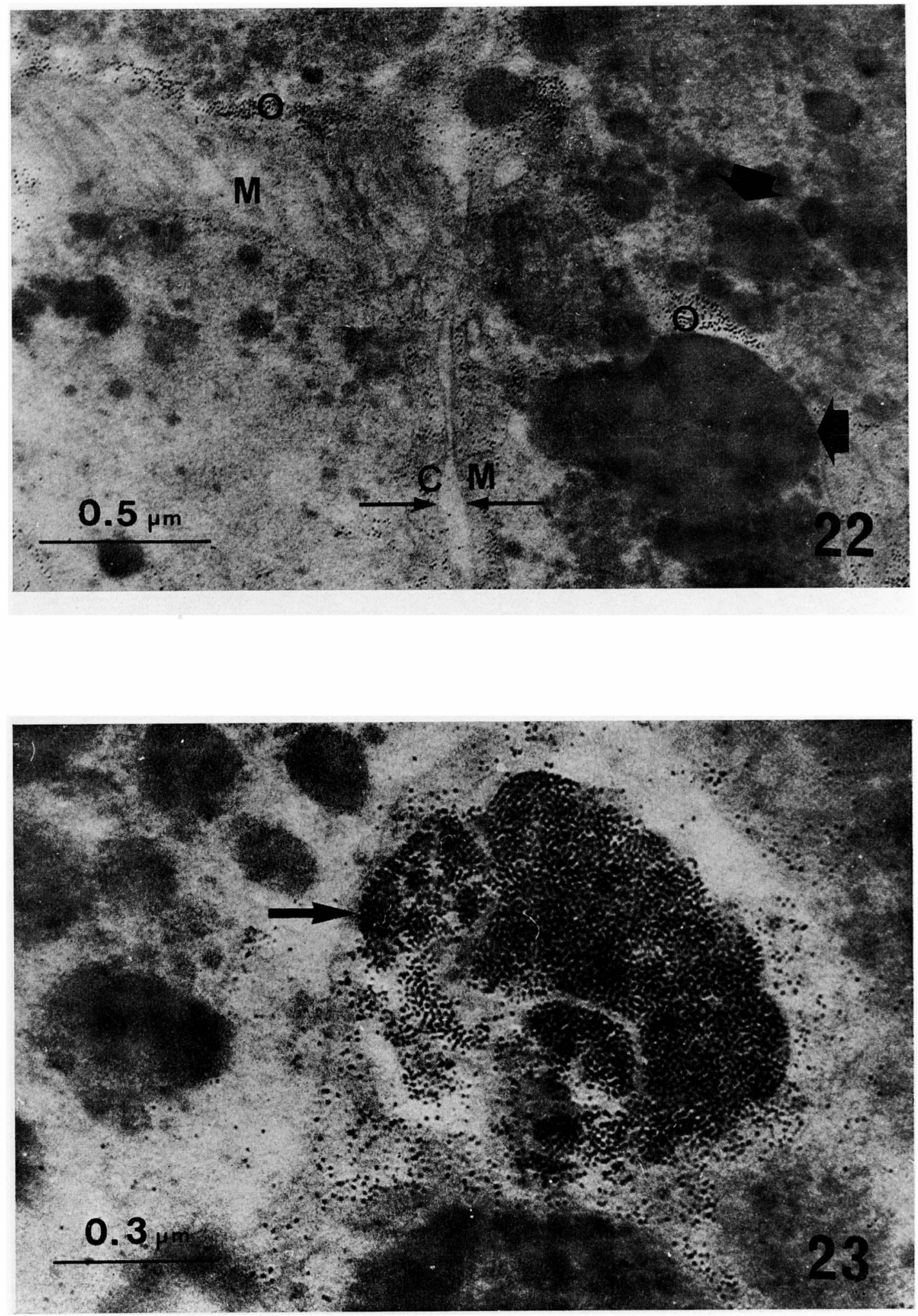


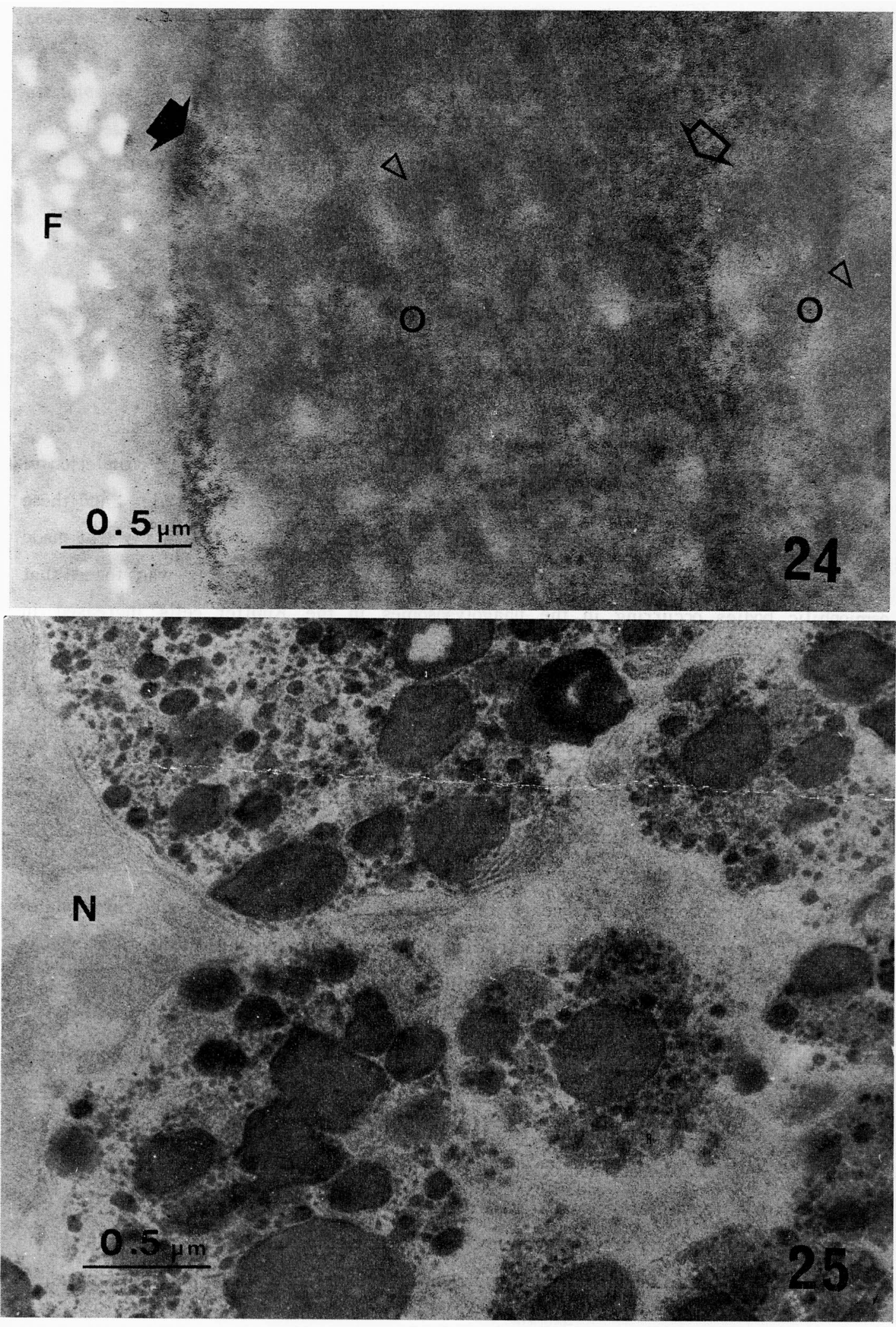




\title{
（欧 文 抄 録）
}

\section{An Electron Microscopical Study on the Production of Ceroid, Hemosiderin or Ferritin in the Liver of Mice Repeatedly Forced to Inhale Carbon Tetrachloride Vapor}

\author{
Jiro Tateiwa \\ Department of Pathology, Kansai Medical University, \\ Moriguchi, Osaka, Japan \\ (Supervised by Prof. R. Maeda)
}

Mice were made to inhale carbon tetrachloride $\left(\mathrm{CCl}_{4}\right)$ vapor 5 to 103 times (at a rate of three times a week); the liver was collected from the mice after completion of inhalation, and prepared chiefly into Epon sections without electron staining; and these sections were examined under the electron microscope for the yellow-brown pigment made up of ceroid and hemosiderin that appeared in the Kupffer cells. It was found that osmiophilic bodies occurring in the phagolysosomes in the Kupffer cells increased in number as well as in size, and were fused with each other as the experimental period was prolonged, the giant phagolysosomes being filled with ceroid granules made up of clusters of osmiophilic multivacuolar structures and osmiophilic fingerprint-like structures at the end of the experiment over a longer period.

The ferritin-like particles appeared scattered or as clusters or in the shape of siderosomes in the cytoplasmic matrix. The clusters were also seen protruding out of the limiting membrane of phagolysosomes in such a way as if budding, and thus being pushed out of the phagolysosomes. Subsequently the ferritin-like particles or hemosiderin granules mentioned above were identified by their disappearance following the dithionite desiderization method (the tissue piece method) applicable to the ultrastructural level.

On the other hand, the participation of erythrocytes in ceroid formation could be confirmed by the fact that erythrocytes engulfed by Kupffer cells are frequently found in the giant phagolysosomes where ferritin-like particles or hemosiderin granules are coexistent with ceroid granules. These findings are thought to support the view of Maeda et al. that erythrocztes may become common origin of ceroid and hemosiderin.

In the carbon tetrachloride inhalation experiment over a long period, the Kupffer cell came to include numerous large phagolysosomes filled with ceroid granules, while ferritinlike particles or hemosiderin granules were hardly found except in the rim of phagoly- 
sosomes in the same cell. This finding suggests that with the process of the $\mathrm{CCl}_{4}$ inhalation experiment, ceroid granules greatly accumulate in the cytoplasm, while hemosiderin granules in the cytoplasm decrease gradually through lysosomal discharge ("reverse pinocytosis") into the cytoplasmic matrix in the shape of ferritin particles. 